\title{
New seismo-stratigraphic data of the Volturno Basin (northern Campania, Tyrrhenian margin, southern Italy): implications for tectono-stratigraphy of the Campania and Latium sedimentary basins
}

\author{
Gemma Aiello $^{1,{ }^{\star}}$, Anna Giuseppa Cicchella ${ }^{2}$, Vincenzo Di Fiore ${ }^{1}$, Ennio Marsella ${ }^{1}$ \\ ${ }^{1}$ Istituto per l'Ambiente Marino Costiero (IAMC), Consiglio Nazionale delle Ricerche, Sede di Napoli, Calata Porta di Massa, Naples, Italy \\ ${ }^{2}$ Università degli Studi di Napoli «Federico II», Dipartimento di Scienze della Terra, Naples, Italy
}

\author{
Article history \\ Received July 29, 2010; accepted March 14, 2011. \\ Subject classification: \\ Northern Campania continental margin, Volturno Basin, Seismic stratigraphy, Multi-channel seismics, Depositional geometries.
}

\section{ABSTRACT}

A geological section of the Volturno Basin (northern Campania, continental margin, Italy) has been constructed based on new multichannel seismic data, to show the stratigraphic relationships between the filling in the Quaternary basin and the Meso-Cenozoic acoustic basement. The new seismic sections presented here outline the underlying structures of the basin and their relationships to the filling in the Quaternary basin. Deep exploration wells in Campania and Latium on the Tyrrhenian margin have gathered litho-stratigraphic and commercial multi-channel seismic data that can be used for better integration of the geological data for the area under study. The trending of the seismic units is controlled by the Massico Structural High, which forms the boundary of the Volturno Basin towards the north-west. This produces a geometry that is characteristic of a fan complex, with NE-SW trending. This qualitative calibration of the seismic sequences that fill the sedimentary basin was carried out through the litho-stratigraphic data of the "Castelvolturno 2" well, which highlights the pyroclastic layers and conglomeratic strata of the lagoon and delta environments as they evolve upwards towards marine sediments. Seismo-stratigraphic analysis shows the complex depositional geometries of the filling in the Volturno Basin, which overlie the MesoCenozoic carbonatic basement and the related flysch deposits. Coupled with regional geological evidence, the data interpretation here suggests that the Volturno Basin represents a half-graben structure that is characterized by down-thrown blocks along normal faults.

\section{Introduction}

The acquisition of new multi-channel seismic data for the Volturno Basin (northern Campania, continental margin, Italy) has allowed the construction and interpretation of its geological section. This shows the stratigraphic relationships between the filling in the Quaternary basin and the underlying Meso-Cenozoic carbonatic acoustic basement and related flysch deposits. The seismic sequences and the underlying basement structure are located through seismostratigraphic criteria.

The seismic lines presented here outline a geological picture of the deep structures of the investigated area, with particular reference to the stratigraphic relationships between the Meso-Cenozoic acoustic basement and the filling in the Quaternary sedimentary basin. Deep exploration wells in Campania and Latium of the Tyrrhenian margin [Ippolito et al. 1973, Ortolani and Aprile 1978] have supplied litho-stratigraphic data that have been used to define the commercial seismic profiles.

The new stratigraphic and structural data collected in the Volturno Basin (Sister4_2 multi-channel seismic line) have been compared with commercial seismic data of «Zone E» (AGIP), with particular attention to the Terracina and Gaeta Basins, which are examples of half-graben basins and are located on the Campania-Latium Tyrrhenian margin [Aiello et al. 2000] (Figure 1). This has allowed better geological interpretation of the new seismic line, which has been put into the framework of the regional geological context through the re-interpretation of some of the profiles from the commercial seismic data. All of the three basins (Volturno, Terracina and Gaeta) show the formation of wide deltaic systems on the Pleistocene continental shelf that are genetically related to the rivers that crossed the adjacent coastal belt and formed the alluvial plains of Latium (Pontina and Fondi Plains) and Campania (Garigliano and Volturno Plains).

\section{Data and methods}

\subsection{Multi-channel seismic data}

A grid of multi-channel seismic lines was acquired in 1999 for the continental margin of Campania, through a joint project (the sister oceanographic cruise of the Seismic 


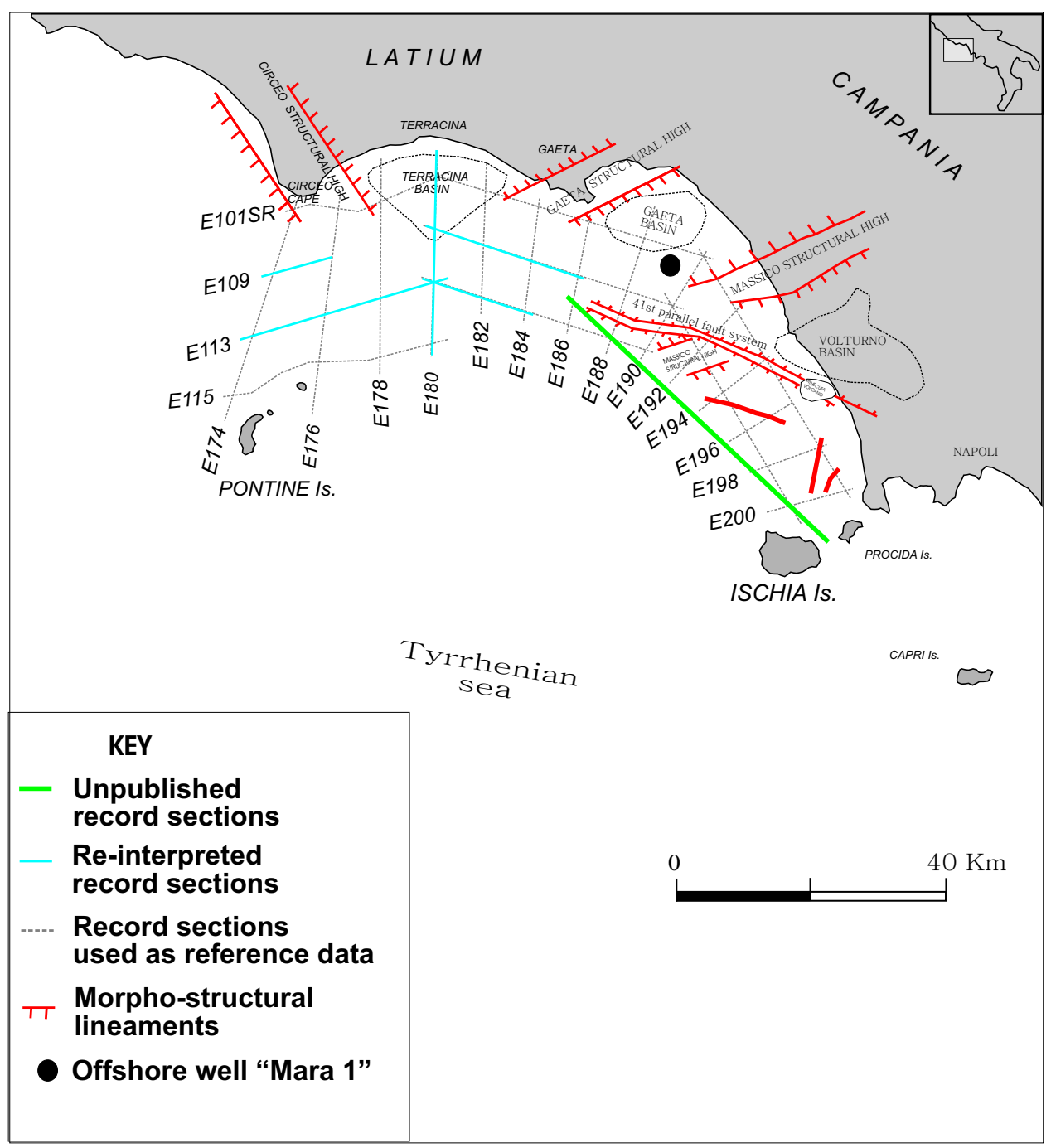

Figure 1. Map of the interpreted seismic sections. Unpublished record sections, re-interpreted record sections and record sections used as reference data are indicated. The regional morpho-structures on the Northern Campania Tyrrhenian continental margin detected through reflection seismic profiles are also shown [after Bartole 1984, Bruno et al. 2000, Aiello et al. 2000, de Alteriis et al. 2006].

Investigations in the South Tyrrhenian Extensional Regions) between the Institute of Marine, Environment and Coastal Areas of the Italian National Research Council (IAMC-CNR, Naples, Italy), the Marine Geology Group of the University of Palermo (Palermo, Italy), and the Department of Tectonics of the Vrije University of Amsterdam (Amsterdam, The Netherlands) [Bertotti et al. 1999, Korevaar et al. 2000]. The main goal of this cruise was the acquisition of data relating to the kinematics of the Tyrrhenian margin formation.

The instruments used and the advanced techniques of multi-channel seismic data acquisition allowed high quality data to be obtained also in the Campania volcanic area. Here, the occurrence of pyroclastic levels and buried volcanic bodies produces strong scattering of the acoustic energy. In particular, new airguns, a new 48-channel streamer, and a new system of data acquisition (geometrics) were used, which belong to the IAMC-CNR in Naples.

The acquisition parameters are the seismic source, the length of the seismogram, the sample interval, the distance between sources, and the distance between hydrophones. The seismic source consisted of two generator-injector (GI) guns (210 cubic inch; SI/Sodera), the length of the seismogram was $5 \mathrm{~s}$, the sample interval was $1 \mathrm{~ms}$, the shot interval was $25 \mathrm{~m}$, and the distance between the hydrophones was $12.5 \mathrm{~m}$.

Dedicated software was used to process the multichannel seismic data analyzed in this study. A processing flow was selected using commercial software. Quality control of the seismic traces was carried out before assigning the field geometry to the data. Seismic trace editing was done to remove noisy traces and spikes that affected the fast Fourier transform. The signal earlier than the first arrivals was muted and an automatic gain control was applied to normalize the amplitudes along the traces. Spiking deconvolution was used to reduce the casual noise and to improve the wavelet seismic resolution. Multiple arrivals were removed using post-stack deconvolution, while a bandpass filter was applied to enhance the signal of interest along the seismic sections. Finally, post-stack 


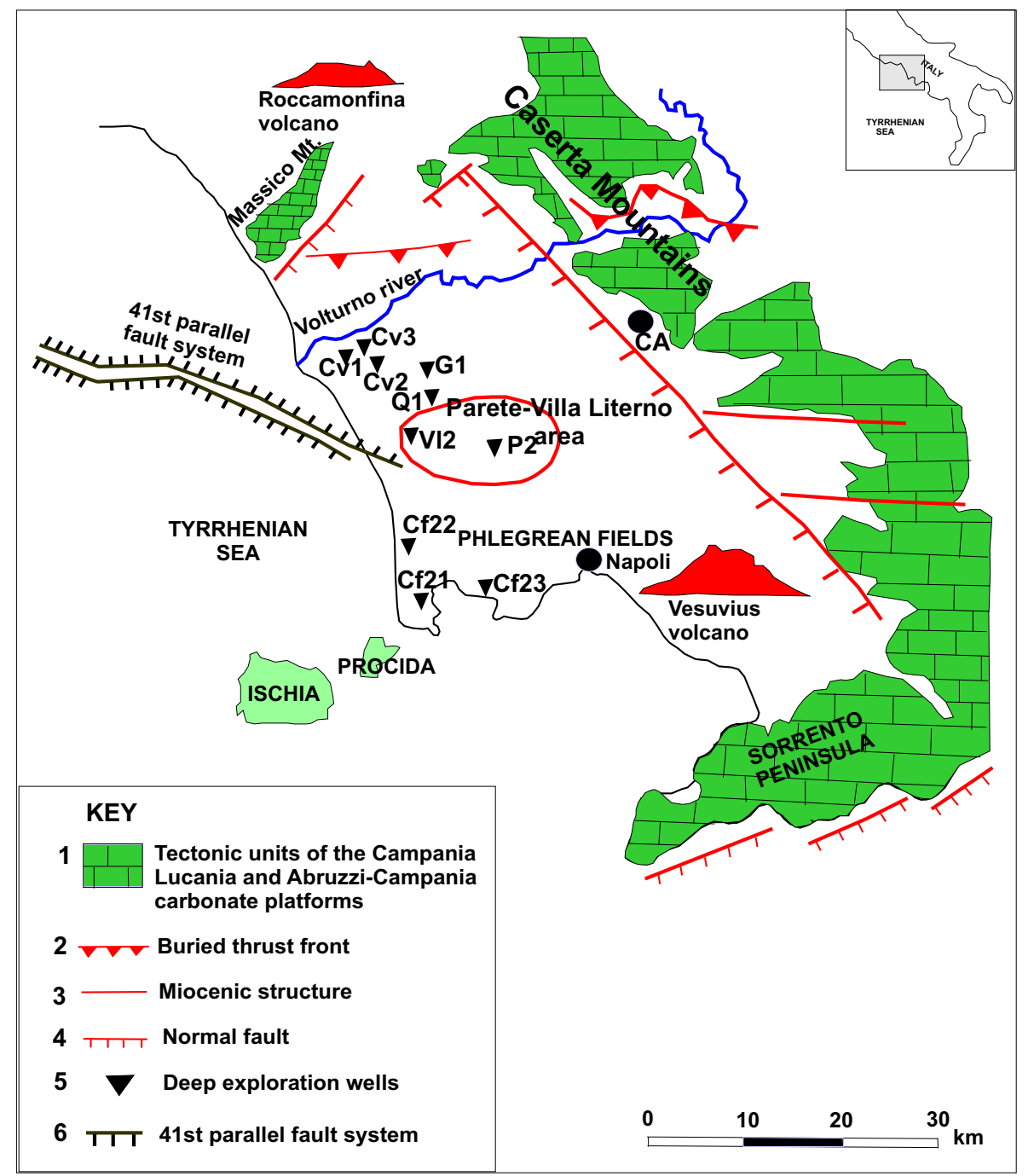

Figure 2. Map of the geology of the area surrounding the Volturno Plain. The location of the deep exploration wells are also shown [from Ippolito et al. 1973, Ortolani and Aprile 1978], onshore in the Volturno Plain, from the mouth of the Volturno River to the Monte di Procida Promontory.

Kirchhoff time migration of the seismic section allowed for correct evaluation of the real dipping of the seismic horizons and faults, to provide an improved and detailed geological interpretation.

The seismic interpretation was carried out based on the criteria of seismic stratigraphy and taking into account the elimination of multiples and of noisy signals from the geological interpretation. The seismo-stratigraphic techniques [Mitchum et al. 1977, Vail et al. 1977] imply the recognition of significant geometries and stratal patterns of the seismic sequences, which were previously identified based on the recognition of the main unconformities.

\subsection{Magnetic data}

During the oceanographic cruise carried out in 2000 onboard the R/V Thetis from the IAMC-CNR, two densely spaced grids of high-resolution magnetic data were recorded, both parallel and perpendicular to the shoreline between Gaeta Gulf and the Ischia and Procida islands, for a total length of $850 \mathrm{~km}$ [Aiello et al. 2005a]. Magnetic data were acquired using the G-811 proton magnetometer on the R/V Urania of the CNR. The accurate positioning of the magnetic data was ensured by the CNR hydro-navigation system. The sensor was placed in a tow-fish located 180 behind the ship, at about $15 \mathrm{~m}$ below sea level. The depth of the magnetometer was regularly measured during data acquisition. The magnetic data were regularly sampled, at intervals of $3 \mathrm{~s}$, which corresponded to $6.25 \mathrm{~m}$ traveled.

Accurate processing of this magnetic data was performed to preserve the information content of the data [Ruggieri 2006]. Initially, the raw data were edited manually or using a nonlinear filter, to remove spikes due to nongeological sources. The marine paths were repositioned, taking into account the offset distance between the fish and the GPS positioning system. Elimination of the diurnal component was carefully controlled for, adopting as reference signal the data recorded at the geomagnetic observatory in L'Aquila (latitude range $41.6^{\circ}-42.8^{\circ} \mathrm{N}$, longitude range $13.0^{\circ}$ $14.3^{\circ} \mathrm{E}$ ) [Masci et al. 2008] kindly supplied by the Istituto Nazionale di Geofisica e Vulcanologia (INGV, Rome, Italy). 
The measuring periods were characterized by quiet magnetic activity. For further details concerning the magnetic data processing, see Ruggieri [2006].

\subsection{Deep exploration wells}

The stack sections were calibrated with the lithostratigraphic data of the deep exploration wells located onshore on the Volturno Plain [Ippolito et al. 1973, Ortolani and Aprile 1978]. The locations of the deep exploration wells (Castelvolturno 1, Castelvolturno 2, Castelvolturno 3, Grazzanise 1, Qualiano 1, Villaliterno 1, Parete 2, Campi Flegrei 21, Campi Flegrei 22; Villa Literno 2) are shown in the geological map in Figure 2. The schematic stratigraphy of the deep boreholes (after Ippolito et al. [1973] slightly modified) is plotted in Figure 3. The Castelvolturno 1, 2 and 3 wells were drilled through thick pyroclastic and alluvial deposits, which represent the basin filling of the Volturno Plain. Similar successions for the northern sector of the Campania Plain were drilled, as the Campi Flegrei 21 and Campi Flegrei 22 wells. On the other side, the Villa Literno 2 and Parete 2 wells were drilled through thick volcanic complexes (Villa Literno volcanic complex and Parete volcanic complex) [Ippolito et al. 1973, Ortolani and Aprile 1978].

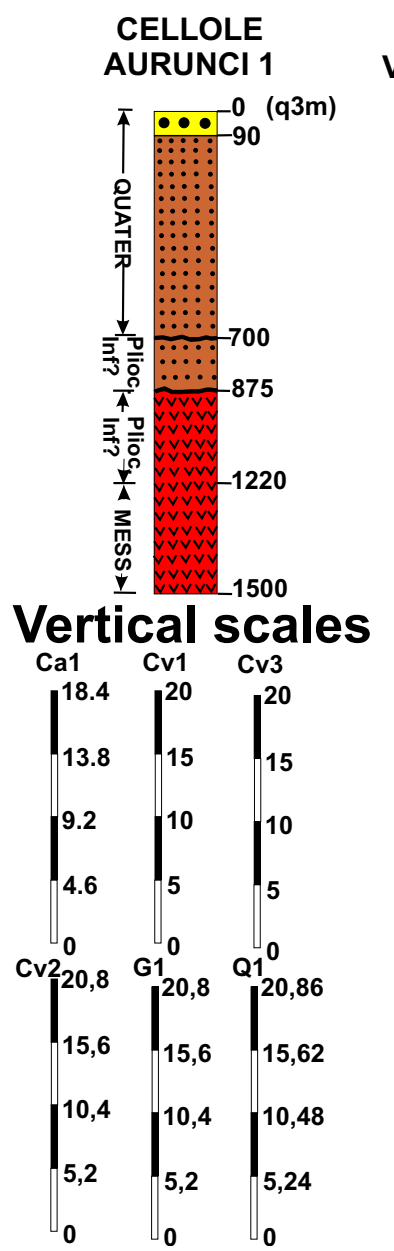

\section{Geologic setting}

The Campania and Latium Tyrrhenian margin includes tectonic domains that can be recognized along the centralsouthern Tyrrhenian offshore between the Ostia-Anzio coast (Latium; Figure 2) and the Policastro Gulf (Campania). On the Campania and Latium margins, Quaternary basin fillings overlie submerged 'internal' (western) tectonic structures of the Apennine chain, which result from the seaward extension of the tectonic units cropping out in the coastal belt of the central and southern Apennines [D'Argenio et al. 1973, Parotto and Praturlon 1975]. These units usually form the acoustic basement of the coastal basins, and they are composed either of terrigenous-shaly basinal sequences («Units Sicilidi», «Units Liguridi», «Flysch of Frosinone», «Flysch of Cilento») [D'Argenio et al. 1973, Parotto and Praturlon 1975] or of thick platform and basinal carbonates. Both such sequences are widely exposed on the adjacent mainland [Bartole et al. 1983, Bartole 1984].

The tectonic extension that accompanied the uplift of the southern Apennines that began in the Early Pliocene and continued to the Early-Middle Pleistocene had a major role in the present-day physiography of the Campania and Latium Tyrrhenian margin. Quaternary marine and

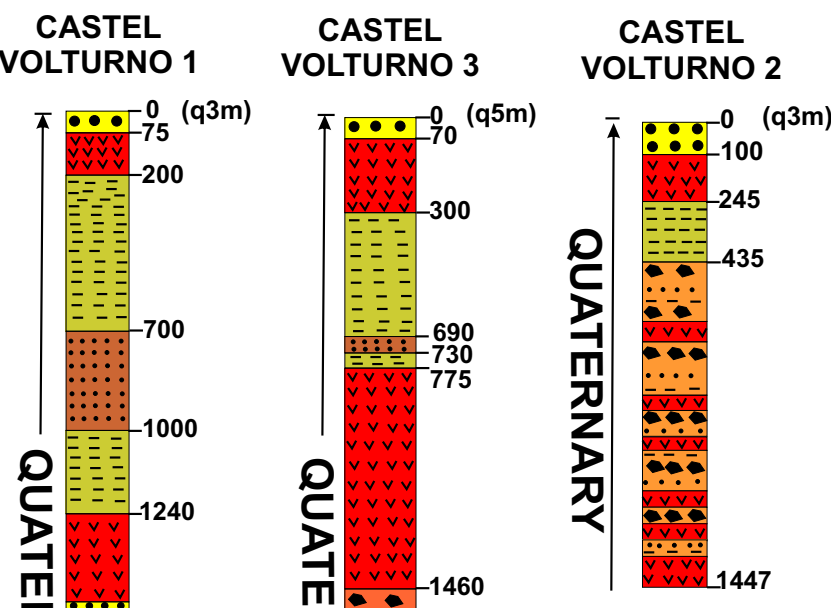

\section{GRAZZANISE 1 QUALIANO 1}

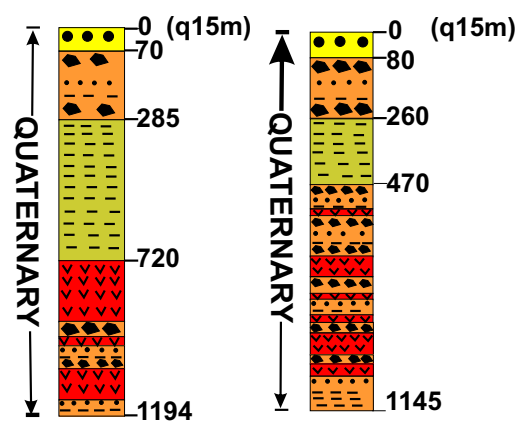

Figure 3. Schematic stratigraphy of the deep boreholes of the Volturno Plain (after Ippolito et al. [1973], slightly modified). 
continental sediments of the Campania coastal plains reach a thickness of up to $3000 \mathrm{~m}$ in the Volturno Plain [Ortolani and Torre 1981]. NW-SE, NE-SW and E trendings are postorogenic structures (mainly extensional faults) that were previously recognized for the Campania and Latium margin [Bartole et al. 1983]. While the Apennine (NW-SE) trending structures characterize the continental slope areas between the Pontine Islands and Cilento Promontory, the counterApennine (NE-SW) trending often occurs offshore between the Salerno Gulf and the Sorrento Peninsula, simulating a basin and ridge marine structure.

Seismic profiles offshore of the central-southern Apennines [Latmiral et al. 1971, Bartole 1984, Mariani and Prato 1988] show that the peri-Tyrrhenian basins south of the $41^{\text {st }}$ parallel are affected by extension parallel to the strike of the fold and thrust belt. On land, the Late Miocene marine deposit outcrop distribution and facies evolution suggests a complex coastal landscape with shallow-water environments for large areas of the early Tyrrhenian basin [Ortolani and Aprile 1978]. Large continental shelf areas are localized along the south-eastern Tyrrhenian margin. Delta systems are fed by the main rivers (i.e. the proto-Tiber). Starting from the Messinian, shallow-water sediments lapped onto downfaulted blocks, and accommodation space was rapidly created throughout the Lower-Middle Pliocene along the whole south-eastern Tyrrhenian margin. Later tectonic extension was caused by a generalized uplift of the mountain belt and renewed subsidence at the basin centers, and uplift at the basin flanks, and it controlled the local structural evolution of coastal half graben systems, where the maximum throw reached was up to $3 \mathrm{~km}$ [Mariani and Prato 1988].

The vertical movements on the eastern margin of the Tyrrhenian basins were recently reconstructed by Ascione and Romano [1999], who recognized a succession of alternated uplift and subsidence episodes during the Early and the Middle Pleistocene. Their cessation in the Late Pleistocene is demonstrated by the Late Pleistocene strandlines at an elevation comparable to the $130 \mathrm{ky}$ sea-level high stand. Since the beginning of the Santernian, the absolute vertical movement accounted for uplift of the mainland of $400 \mathrm{~m}, 150 \mathrm{~m}$ of which occurred in the Middle Pleistocene. Other structural highs bordering the Tyrrhenian basinal depressions provide evidence of subsidence episodes that interrupted the prevailing uplift trend recorded during the Quaternary.

The stratigraphy of the subsurface of the Volturno Plain is well known because the area has been intensively explored by oil companies (AGIP and ENEL, Italy). The borehole data reveal a Plio-Quaternary sedimentary succession that is composed of alluvial deposits (sands and conglomerates) and by marine and transitional sediments, with the insertion of lava and pyroclastic deposits [Ortolani and Aprile 1978, Mariani and Prato 1988, Brancaccio et al. 1991] (Figure 3).
The depocenter of the Neogene succession has been observed in correspondence with the mouth of the Volturno River, where a sedimentary thickness $>2500 \mathrm{~ms}$ is reached (corresponding to $3500 \mathrm{~m}$ to $4000 \mathrm{~m}$ deep; the Castelvolturno 1 and 3 wells) (Figure 3). On the other hand, the Mesozoic carbonates basement was down-thrown by synsedimentary listric faults, which gave rise to wedging geometries during the Pleistocene [Mariani and Prato 1988].

The area can be divided into two sectors with different geological and geophysical characteristics: north and south of the $41^{\text {st }}$ parallel; and in correspondence with the mouth of the Volturno River. These differences regard mainly the seismic stratigraphy of the sedimentary units and the occurrence southward of this boundary of a well-developed magnetic anomaly field, with a complex trending [Fedi and Rapolla 1987].

The pre-Miocene basement coincides with the acoustic basement seen with the seismic reflection profiles. This acoustic basement is frequently composed of Mesozoic carbonates that correlate with the "Abruzzi and Latium carbonate platform» tectono-stratigraphic units [D'Argenio et al. 1973], which widely crop out in the Aurunci and Massico Mountains. As observed in other sectors, the acoustic basement coincides with the top of buried volcanic edifices, both onshore and offshore [Zitellini et al. 1984, Mariani and Prato 1988, de Alteriis et al. 2006].

The geomorphological evolution of the Volturno plain between Middle Pleistocene and Holocene times was reconstructed by Romano et al. [1994] based on outcrop data and boreholes. The age model relies on $\left[{ }^{230 \mathrm{Th}}\right] /\left[{ }^{234} \mathrm{U}\right]$-dating of fossiliferous layers in the cores. The succession is made up of six stratigraphic units. The lowermost is represented by marine sediments, the top of which date from $126 \mathrm{ky}$ B.P. to 42 ky B.P. and correlates with two pumice outcrops on the eastern edge of the Volturno plain. The second unit is constituted of pyroclastic and lavic deposits, which correlate with two pumice outcrops on the eastern edge of the Volturno plain. The third unit is composed of transitional and marine deposits that are related to isotopic substage 3.3, and date to $55 \mathrm{ky}$ B.P. to $50 \mathrm{ky}$ B.P. The fourth unit is the Campanian Ignimbrite Auct., and dates to $42 \mathrm{ky} \mathrm{B.P.} \mathrm{to} 27 \mathrm{ky}$ B.P. [Scandone et al. 1991]. The fifth unit is represented by locally reworked pyroclastic deposits of the fourth Phlegrean period [Di Girolamo et al. 1984]. Finally, the sixth unit is composed of clays, silt and peat layers of lagoonal environments that are Holocene in age (10 ky B.P. onwards). The sedimentation has been influenced by the nonhomogenous tectonics. During the first half of the upper Pleistocene, the whole area was subsiding, with a higher rate in the south-western sector. Despite pyroclastic aggradation, a marine environment lasted throughout the period in the central sector of the plain. In the latter part of the upper Pleistocene, reduced subsidence and negative glacio-eustatic 


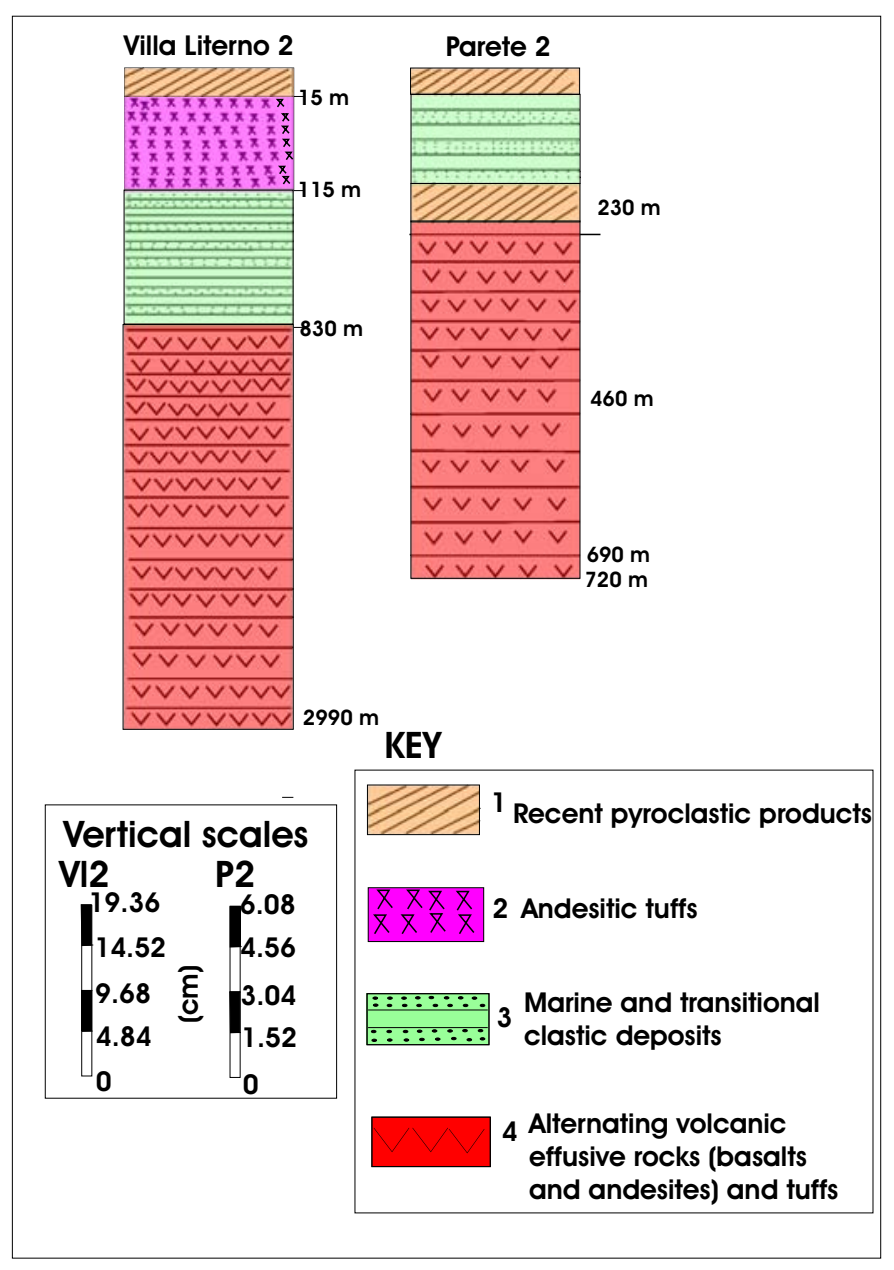

Figure 4. Schematic stratigraphy of the «Villa Literno 2» and «Parete 2» lithostratigraphic wells (modified from Ortolani and Aprile [1978]).

fluctuation led to total emersion of the plain; subaerial erosion dates back to this period. Tectonic uplift of some tens of meters at the north-eastern edge of the plain also took place. Moreover, morphological and archeological data indicate the continuation of tectonic uplift in historical times. The central and coastal sectors of the plain have not been affected by tectonic activity since the deposition of the Campanian Ignimbrite. This area was progressively invaded by the sea during the Versilian transgression.

The structural features related to the $41^{\text {st }}$ parallel fault zone (Figure 1), which include the onshore OrtonaRoccamonfina line, have been studied recently by Bruno et al. [2000], who revealed ESE-WNW to E-W and NE-SW striking faults. The activity of these faults developed during Pliocene-Early Pleistocene times. The ESE-WNW to E-W faults show structures consistent with strike-slip movements. These faults are responsible for the SSE translation of the seaward prolongation of the Mount Massico horst. The dislocation of Mount Massico suggests left-lateral movements for the strike-slip faults. The NE-SW faults that affect the Mount Massico horst show seismic features that are consistent with normal movements, as also revealed by onshore seismic data. On the Campania-Latium Tyrrhenian margin, both the Ortona-Roccamonfina line and the $41^{\text {st }}$ parallel fault system appear to be inactive now. The $41^{\text {st }}$ parallel fault system represents a deep-seated transfer fault system that was formed as a response to different rates of the Tyrrhenian sea opening. The strike-slip and the normal movements along the $41^{\text {st }}$ parallel fault and the OrtonaRoccamonfina faults, respectively, are consistent with a NW-SE (Apenninic) extension.

A boundary analysis of gravity and magnetic fields of the Phlegrean volcanic area and Campania Plain revealed a complex structural setting [Florio et al. 1999]. The Campania Plain is well defined from sharp density boundaries. A set of major E-W lineaments occurs within the plain. The volcanological evolution of the plain appears to have been strongly influenced by NE-SW lineaments, bordering the Acerra graben. The density and the magnetization boundaries of the Phlegrean Fields are consistent, which indicates a less extended area for the collapsed Phlegrean caldera, with respect to the area identified based on previous geologically defined models. Inside the caldera, there has been strong consistence between the structures identified and the recent seismicity.

Rolandi et al. [2003] recently indicated the tectonic controls on the genesis of ignimbrites from the Campania volcanic area. The Campanian Ignimbrite represents the largest eruption volume; it was vented from pre-existing neotectonic faults, and was formed during the Apenninic uplift. During the eruption, the Acerra graben, which was already affected by a NE-SW fault system, was transected by E-W faults that formed a cross-graben that extended to the Bay of Naples. The E-W faults were further dislocated by NE-SW strike-slip movements. The pumice fall deposit underlying the Campanian Ignimbrite deposits, which until now was thought to be associated with the Campanian Ignimbrite eruption, is not a strict transition from Plinian to Campanian-Ignimbrite-forming activity. This deposit is derived from an independent source that was located near the Naples area. This initial volcanic activity is assumed to be a precursor to the Campanian Ignimbrite trachytic eruptions, which vented along regional faults.

\subsection{The Parete and Villa Literno volcanic complexes}

Since the Late Miocene, intense volcanism has characterized the Campania Plain. On its western border, the volcanic activity has close spatial relationships with NE-SW (counter-Apennine) normal faults [Florio et al. 1999, Rolandi et al. 2003]. The volcanic products of the Campania volcanism belong to two cycles: the older one is of Miocene to Pleistocene in age, and was characterized by calcalkaline, andesitic and basaltic lavas, which have been found only in the Parete 2 and Villa Literno 2 wells (the «Parete» and «Villa Literno» volcanic complexes) [Baldi et al. 1976, Barbieri et al. 1976, Di Girolamo et al. 1984, Rosi and Sbrana 1987, Barberi 


\section{LINE E-180}

S
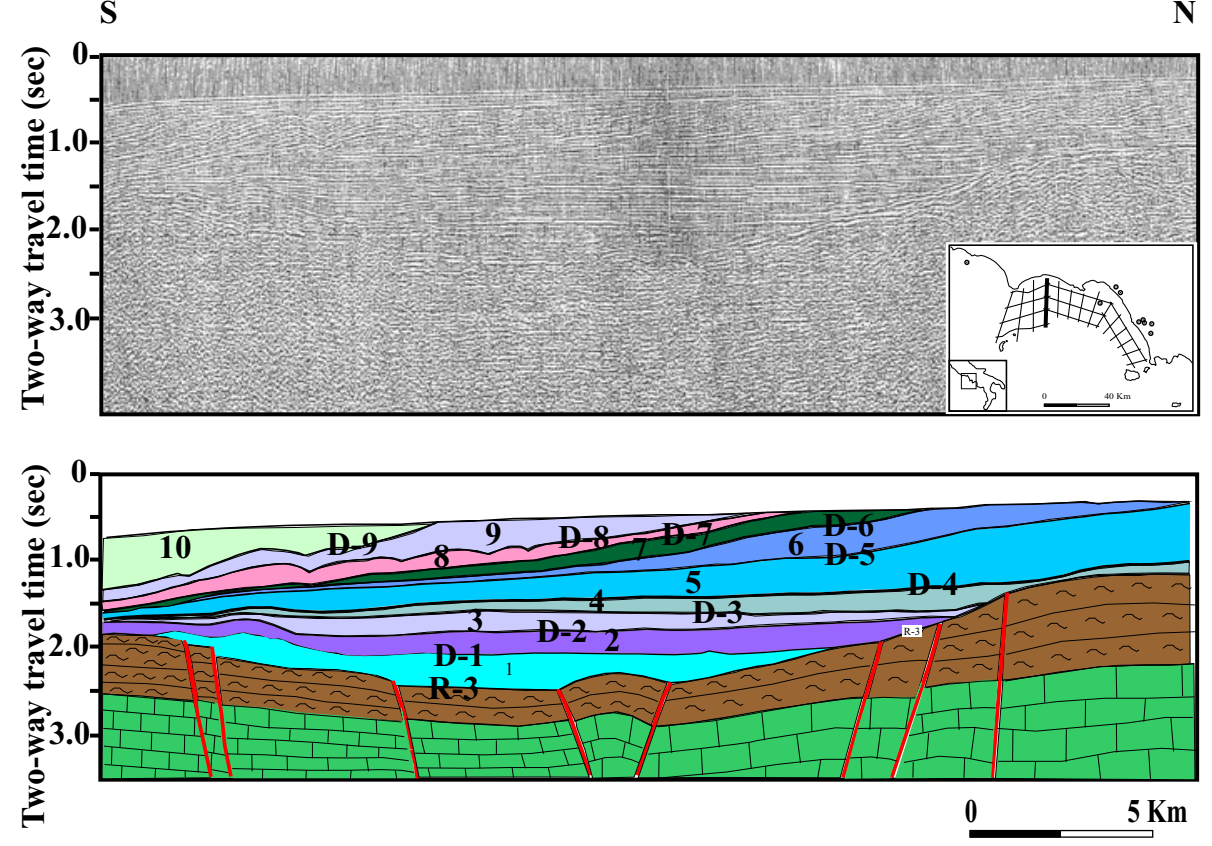

Figure 5. E180 seismic profile (re-interpreted from Aiello et al. [2000]), showing the stratigraphy of the Terracina Basin. Ten seismic sequences are bounded by regional unconformities that correspond to on-lap and/ or down-lap surfaces, and, in the upper part of the basin fill, to erosional truncations. Regional unconformities: R-3, D-1, D-2, D-3, D-4, D-5, D-6, D-7, D-8, D-9). Seismic sequences: 1, 2, 3, 4, 5, 6, 7, 8, 9 and 10. The lower group of seismic sequences (1-4) shows seismic facies with parallel reflectors on-lapping the top of the acoustic basement and appears locally involved by normal faulting, testifying a synsedimentary nature of these strata. The reflector D4 represents a tectonically-enhanced unconformity, which marks the beginning of the progradation in the basin fill, as seen by five prograding seismic sequences (5-10).

et al. 1991, Brocchini et al. 2001]; the younger cycle is distinguished from alkaline-potassic products, and is related to the Plio-Pleistocene extensional tectonics that characterized the Roman co-magmatic province and includes Vesuvius and the Phlegrean Fields. The starting age of the volcanism in the area is still a matter of scientific debate [Rosi and Sbrana 1987]. Sequences of lavas and pyroclastic products dated at about 2 million years were found in the Villa Literno 2 and Parete 2 deep boreholes [Barbieri et al. 1976, Di Girolamo et al. 1984, Rosi and Sbrana 1987]. Volcanic products older than $350 \mathrm{ky}$ were found in the Apenninic area [De Vivo et al. 2001], and on Vesuvius [Brocchini et al. 2001] and Ischia [Gillot et al. 1982].

The deep structure of the Parete-Villa Literno area has been studied since the early 1970's through geological and geophysical surveys. Based on a gravimetric survey, Maino et al. [1963a, 1963b] interpreted the positive gravimetric maximum of the Parete area as having been caused by a thick buried lava complex. The same gravimetric maximum was interpreted by Oliveri Del Castillo [1966] as having been caused by a structural high of the Meso-Cenozoic carbonatic basement. The same study hypothesis was later modified by Carrara et al. [1973, 1974] and Cameli et al. [1975], taking in the same buried carbonatic horst at depths between $1100 \mathrm{~m}$ and $1500 \mathrm{~m}$. They explained the positive magnetic anomalies as due to isolated lava bodies that form intrusions along the faults. After the drilling of the Parete 2 exploration well, Baldi et al. [1976] suggested the occurrence of a thick lava complex (the Parete volcanic complex), overlying a NW-dipping monoclinalic structure, constituted by carbonatic rocks.

The litho-stratigraphic attribution of the Parete and Villa Literno volcanic complexes were later described by Ortolani and Aprile [1978], who showed the stratigraphy of the corresponding wells (Figure 4). In the «Villa Literno 2» well, west of Parete, below recent pyroclastic products the drill site encountered andesitic tuffs (about $150 \mathrm{~m}$ thick) overlying marine and transitional clastic deposits (about $650 \mathrm{~m}$ thick). Alternating basalts-andesites and tuffs were encountered at depths between $830 \mathrm{~m}$ and $2980 \mathrm{~m}$. The borehole reached a maximum depth of $2990 \mathrm{~m}$, crossing lava products about $2150 \mathrm{~m}$ thick that probably continue to increasing depths. In the «Parete 2» drill site (Figure 4), in the Parete area, which is characterized by positive magnetic and gravimetric anomalies, the borehole was drilled through alternating basaltic and andesitic lavas below recent pyroclastic products and clastic deposits that are about $300 \mathrm{~m}$ thick, [Baldi et al. 1976, Ortolani and Aprile 1978] (Figure 4).

\section{Seismic stratigraphy}

On a regional scale, the main morpho-structures of the northern Campania continental margin recognized by the reflection seismic profiles (from the commercial seismic data of «Zone E»; AGIP) are represented by (Figure 1) [Bartole 1984, Aiello et al. 1996, Aiello et al. 2000, Bruno et al. 2000, 


\section{CDP position}

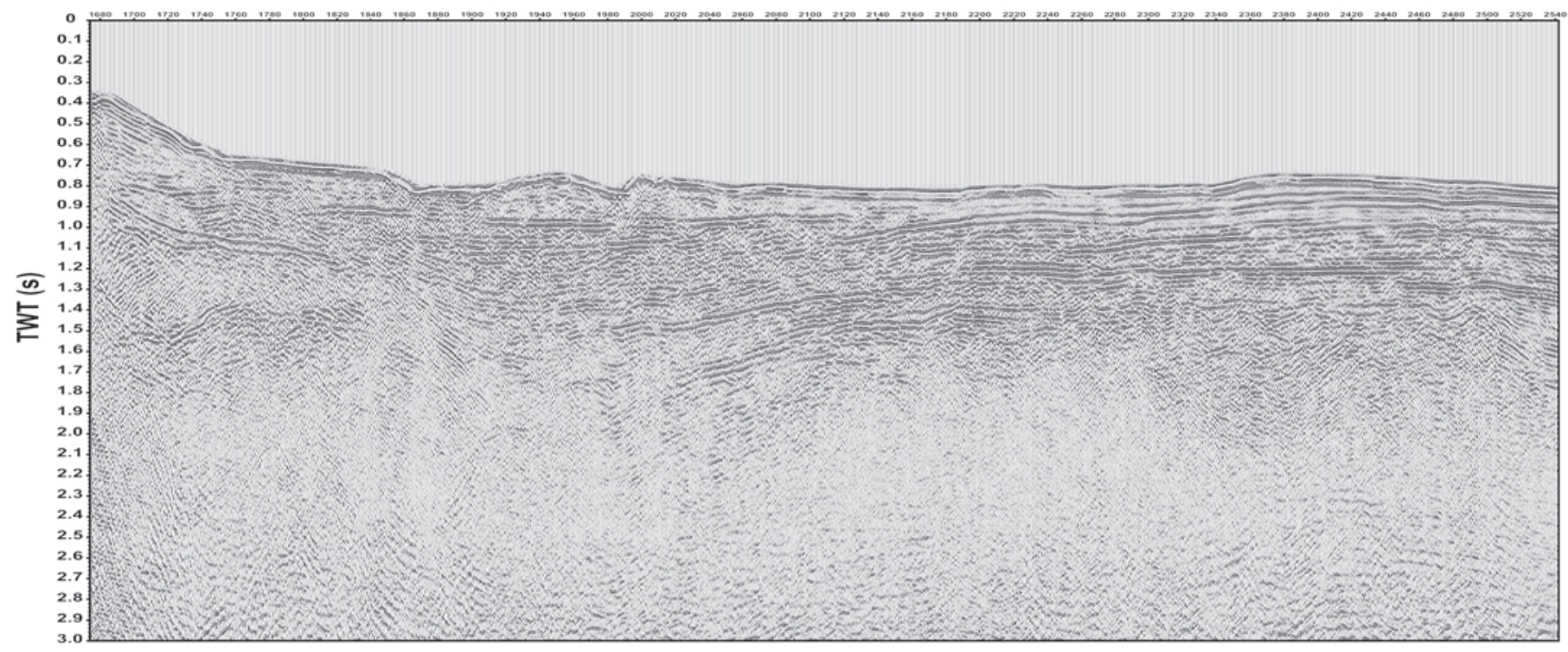

\section{SISTER_4_2_Mig}

Figure 6. Sister4_2 seismic profile (Volturno Basin). See legend to Figure 7 for the geological interpretation of the seismic profile.

de Alteriis et al. 2006]: the Circeo Structural High, with a NW-SE trend and which represents the seaward prolongation of the Circeo Promontory; the Terracina Basin, a N-S trending half-graben basin, which widens seaward and laterally joins with the Gaeta Basin; the Terracina-Gaeta Structural High, a wide belt of structural highs outside of Gaeta town, which represent the physiographic separation between the Terracina and the Gaeta basins; the Massico Structural High, a NE-SW trending structural high, which represents the seaward enlargement of the Massico Mount Structural High; and the Volturno Basin, which is characterized by a depocenter in correspondence with the mouth of the Volturno River, where the basin filling reaches a thickness of $2.5 \mathrm{~s}$.

Large areas of continental shelf have been localized along the southern Tyrrhenian margin, where the deltaic systems were supplied by the main rivers. In the Terracina and Volturno basins, there are wide deltaic complexes on the continental shelf, which are bounded at their base by a tectonically enhanced nonconformity, which fossilized the syn-rift seismic sequences [Aiello et al. 2000].

The stratigraphic setting of the Terracina delta complexes is characterized by ten seismic sequences that are bounded by significant seismic horizons, which correspond to on-lap/down-lap surfaces, and in the upper part of the basin fill, to erosional truncations (Figure 5).

The lower group of seismic sequences shows a seismic facies with parallel reflectors that on-lap the top of the acoustic basement. They appear to be locally affected by significant normal faults, which suggests a synsedimentary nature of these strata. A delta complex that shows vertical and lateral organization of the facies with a 'bottom set', a 'fore set' and a 'top set' has been recognized (Figure 5). This was formed during the Pleistocene by the adjacent alluvial plains of the southern Latium (Fondi Plain and Pontina Plain), and a main NW-SE direction of progradation has been observed. During the Late Pleistocene, a regressive trend of marine and coastal facies is suggested by the progressive basin-ward migration of the off-lap breaks.

The Volturno Basin takes up the northern sector of the Campania Plain, which underwent pronounced tectonic subsidence during Quaternary times. It is bounded to the north-northwest by the NE-SW trending Massico Mount Structural High, to the east by a series of NW-SE striking normal faults, down-throwing the platform carbonates that out-crop in the Caserta Mountains. The Volturno Basin has a volcanic body that is genetically related to the Villa Literno volcanic complex, and to the west, in the surrounding offshore, it is limited by a volcanic structural high that runs parallel to the shoreline and represents a buried volcanic edifice at the mouth of the Volturno River [de Alteriis et al. 2002, 2006].

The maximum development of the sedimentary bodies in the Volturno Basin is conditioned by the Massico Structural High, which forms the boundary of the basin towards the north-west. This produces depositional geometries typical of a NE-SW trending fan complex.

Qualitative calibration of the seismic sequences that fill the sedimentary basin were carried out through the lithostratigraphic data of the "Castelvolturno 2» deep borehole near the town of Cancello Arnone (Caserta; Figures 2 and 3) [Ippolito et al. 1973]. The well was drilled through 
SISTER4_2

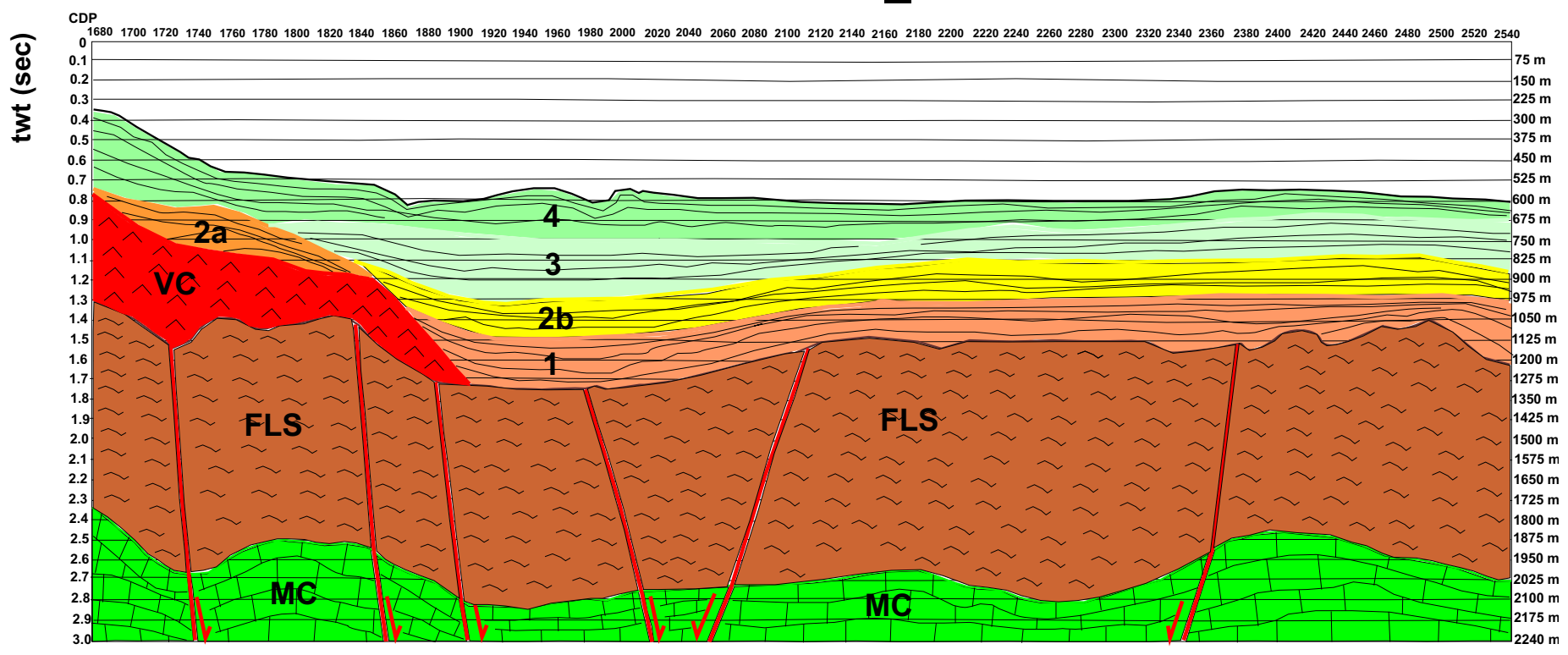

\section{KEY}

4 Seismic unit with parallel to subparallel seismic reflectors, from discontinuous to continuous.

Shales of coastal environment (Pleistocene)

3 Seismic unit with parallel to subparallel seismic reflectors with high amplitude. ù

Alternating sands and shales of deltaic environment (Pleistocene)

(a) Relic prograding wedge downlapping on volcanites genetically related

$2 b$ to the Villa Literno volcanic complex

(b) Seismic unit with discontinuous parallel to subparallel seismic reflectors.

Alternating sands and shales of deltaic environment (Pleistocene)

Seismic unit with parallel to subparallel seismic reflectors, from discontinuous

1 to continuous.

Sands, conglomerates and shales with levels of pyroclastites

VG Volcanic deposits, genetically related to the Villa Literno volcanic complex

$\widetilde{E} \widetilde{S} \approx$ Miocene flysch deposits ("Frosinone Flysch")

MC Meso-Cenozoic carbonates

("Campania-Lucania carbonate platform")
The lithology of the seismic units is inferred from the lithostratigraphic data of the Cancello 1 well and from the paper of Mariani and Prato (1988) -

I bacini neogenici costieri del margine tirrenico:

Approccio sismico-stratigrafico.

Memorie della Società Geologica Italiana, 41, 519-531.

Figure 7. Geological interpretation of the Sister4_2 seismic profile. The lithology was inferred from the lithostratigraphic data of the «Castelvolturno 2» and «Villa Literno 2» boreholes, and defined by additional seismo-stratigraphic data [Mariani and Prato 1988].

alternating pyroclastic levels and conglomeratic deposits of lagoon and deltaic environments, which evolve upwards to marine sediments (Figure 3).

The seismo-stratigraphic analysis of the Sister4_2 seismic profile has shown the depositional geometries of the filling of the Volturno Basin, which overlies an acoustic basement that probably corresponds to the top of the MesoCenozoic carbonates and at depths between $1800 \mathrm{~m}$ and
$1950 \mathrm{~m}$ (Figures 6 and 7). The carbonatic basement is overlain by a thick seismic sequence that is characterized by chaotic seismic facies with scattered discontinuous reflectors, and that shows an evident structure with faulted blocks. The top of this seismic sequence is at depths from $1125 \mathrm{~m}$ to 1350 $\mathrm{m}$. It probably correlates with the Miocene flysch deposits («Flysch di Frosinone» Auct.), which widely crop out in the adjacent emerged sectors of the Latium-Campania Apennines 


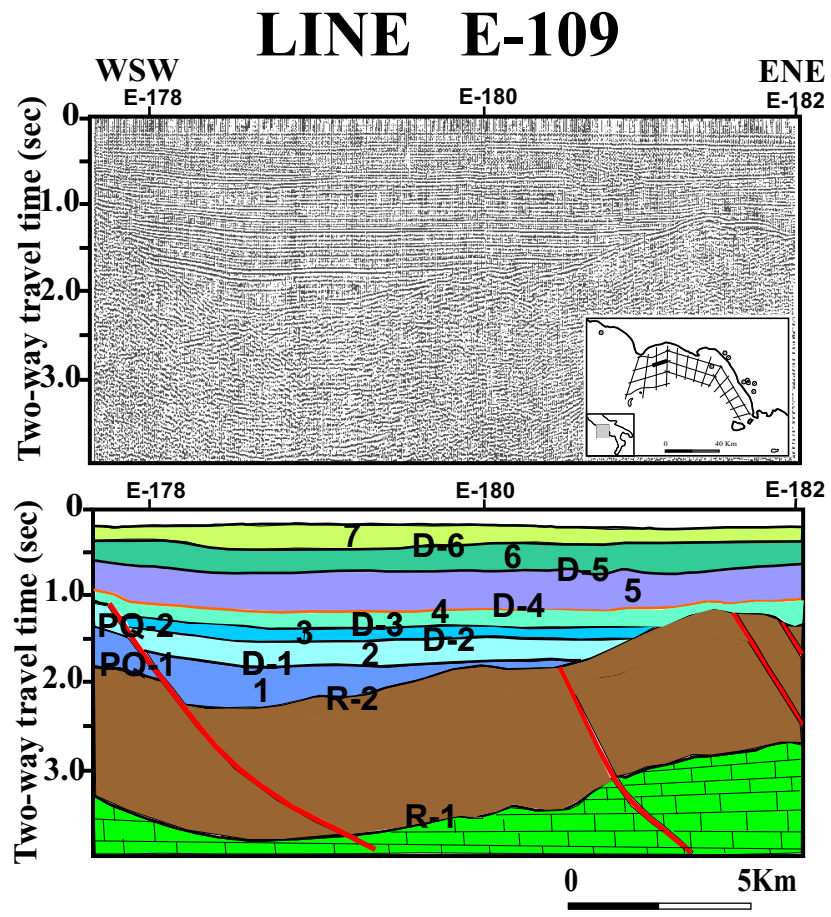

Figure 8. E109 seismic profile (re-interpreted from Aiello et al. [2000]) across the Terracina-Gaeta basin margin. Regional unconformities: R-1, R-2, D-1, D-2, D-3, D-4, D-5 and D-6. Seismic units: 1, 2, 3, 4, 5, 6, 7. Note the master fault, strongly down-throwing the Meso-Cenozoic acoustic basement (throw of less than $1 \mathrm{~s}$ ) and controlling the formation of the half-graben.

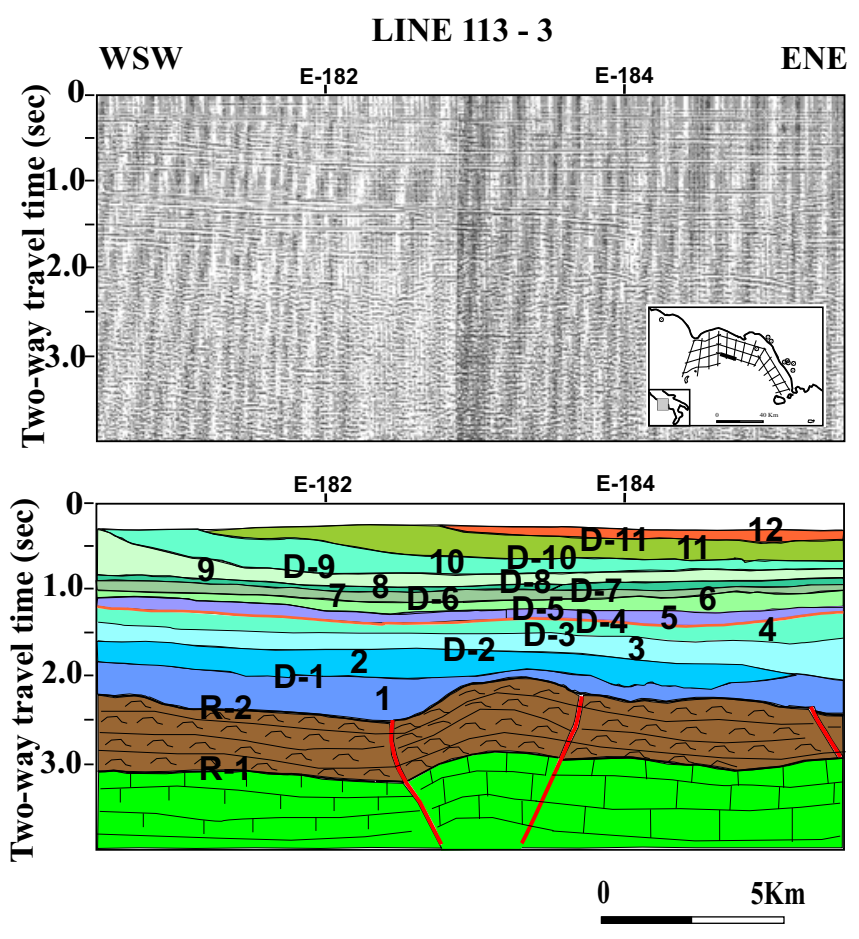

Figure 9. E113 seismic profile (from Aiello et al. [2000], slightly modified) showing the progradational sequences of the Terracina Basin, supplied by the Sisto River (Pontina Plain) during the Pleistocene. Regional unconformities: R-1, R-2, D-1, D-2, D-3, D-4, D-5, D-6, D-7, D-8, D-9, D-10, D-11. Seismic units: 1, 2, 3, 4, 5, 6, 7, 8, 9, 10, 11, 12. A "pop-up" structure in the acoustic basement has also been identified.
[Parotto and Praturlon 1975, Accordi and Carbone 1986].

Relatively complex depositional geometries have been observed in the Volturno offshore through seismostratigraphic interpretation. An acoustically transparent seismic sequence has been interpreted as volcanites (Figure 7, VC), which is Quaternary in age and genetically related to the Villa Literno volcanic complex («Villa Literno 2» well) [Ippolito et al. 1973, Mariani and Prato 1988].

The filling of the Quaternary basin is composed of four main seismic sequences. The first of these is characterized by parallel-to-sub-parallel seismic reflectors, which are from continuous to discontinuous. It shows an evident wedging, which testifies to its deposition during the tectonic activity of normal faults that involved the underlying acoustic basement. On the continental shelf, the second seismic sequence shows evident progradational geometries, which overlies a downlap surface with a low angle (Figure 6, Figure 7, 2a). This has been interpreted as a relic prograding wedge that down-laps on volcanic rocks that are genetically related to the Villa Literno volcanic complex (Figure 7, VC). In the basin, the second seismic sequence is characterized by discontinuous, parallel-to-sub-parallel seismic reflectors, which were probably deposited in a deltaic depositional environment. Both the third and fourth seismic sequences are organized in parallel-to-sub-parallel seismic reflectors, which are from discontinuous to continuous. There are unfilled distributor channels in the uppermost sequence.

The new seismo-stratigraphic data collected for the Volturno Basin confirm that it represents a half-graben (according to Mariani and Prato [1988]) that is characterized by blocks that are down-thrown along normal faults, and which mainly affect the top of the Miocene siliciclastic sequences. Seismo-stratigraphic evidence suggests that the activity of these normal faults probably lasted through a time interval spanning from the end of the Late Miocene (the assumed age of the Frosinone Flysch) [Parotto and Praturlon 1975] to the Early Pleistocene (the assumed age of the first seismic sequence of the basin filling) [Mariani and Prato 1988]. Indeed, the basal sequence shows evident wedging geometries, which indicate its synsedimentary nature.

Similar to the other sedimentary basins offshore of Campania, the volcanic deposits are well developed and interstratified in the sedimentary filling of the basin. This is also the case for a volcanic body that is genetically related to the "Villa Literno" volcanic complex, which can be recognized on the Sister4_2 seismic profile (Figures 6 and 7) and correlates with the Quaternary volcanites drilled by the Villa Literno 2 well (Figure 4) [Ippolito et al. 1973, Ortolani and Aprile 1978]. The emplacement of this volcanic body appears to be successive to the main part of the tectonic extension in the sedimentary basin. However, we cannot exclude that the normal faults represented the preferential route for the magma uprising of the VC volcanic complex. 


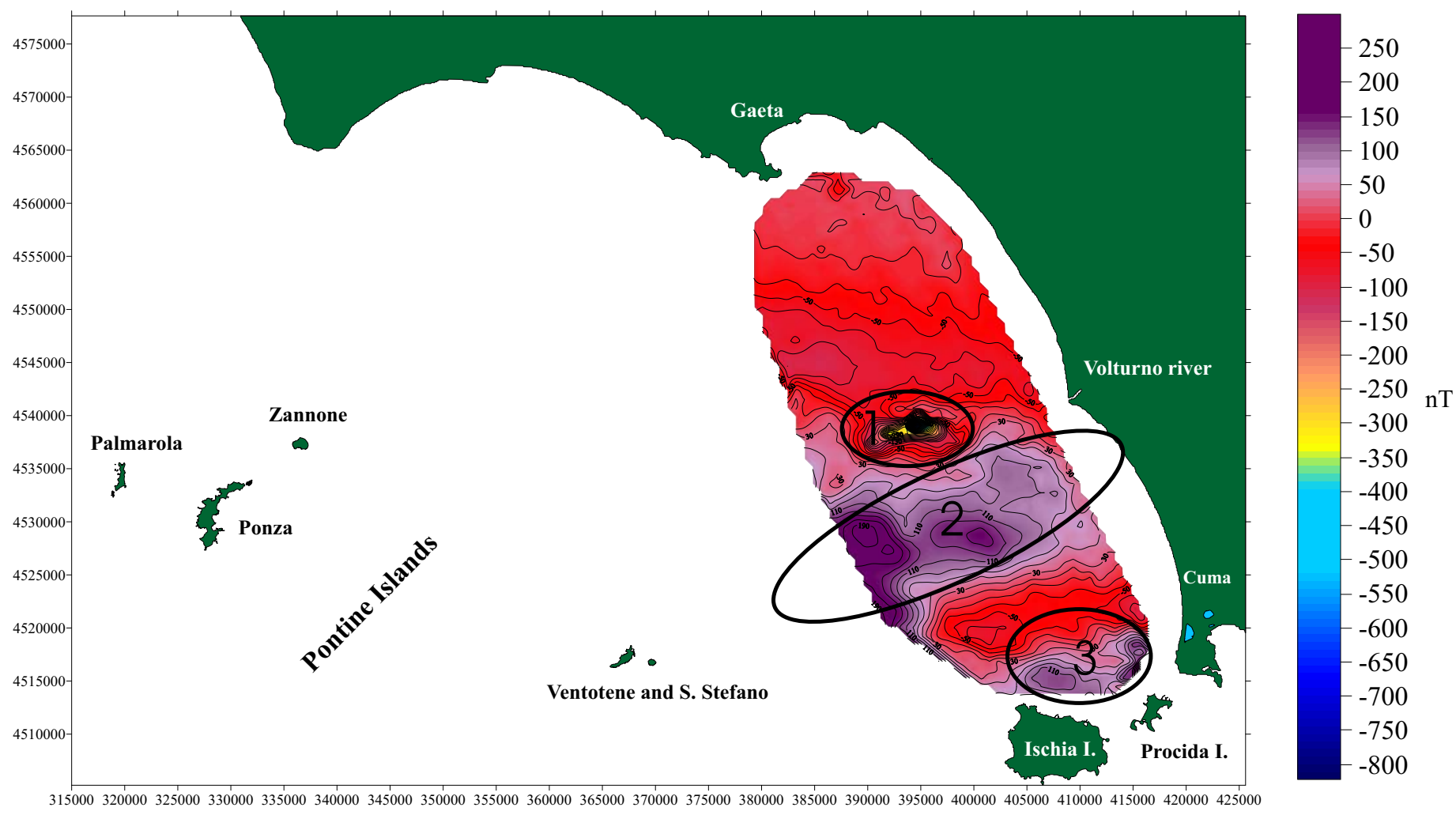

Figure 10. Anomaly map of the total magnetic field offshore between Gaeta Gulf and Ischia Island (reported from Aiello et al. [2005a]; see also Ruggieri [2006]).

Here, direct evidence of normal faulting that corresponds to these volcanites is difficult to assess, as is their detailed relative chronology with the fault systems and their stratigraphic relationship with the filling in the basin, due to the large scattering of the volcanic sequence.

Based on the new seismo-stratigraphic evidence, the tectono-stratigraphic setting of the Volturno Basin agrees with the seismo-stratigraphic evidence collected in the Terracina and Gaeta Basins based on re-interpretation of some of the profiles of the multi-channel commercial seismic data (Figures 8 and 9).

The geological re-interpretation of the E109-2 multichannel profile (Figure 8) shows that the Terracina Basin has a half-graben structure that is roughly N-S trending, and that follows the tectonic extension that acts along systems of normal faults.

Thick prograding strata have been observed in the Terracina Basin, based on the geological interpretation of the E113-3 seismic profile (Figure 9). Wedging and the growth of basal sequences suggest their deposition during the activity of normal faulting.

\section{Geologic correlation between seismic and magnetic data}

The tectono-stratigraphic data for the Volturno Basin that were obtained through the geologic interpretation of the reflection seismics have been compared with the high resolution magnetic data previously collected for the continental shelf between Gaeta Gulf and Ischia Island
[Aiello et al. 2005a, Ruggieri 2006]. The volcanic nature of the geological structures detected in the subsurface has been improved through the magnetic method [Telford et al. 1990]. This kind of analytical approach that is based on the integrated geologic interpretation of seismic and magnetic data has provided good results for the case history of the Bay of Naples [Marsella et al. 2002, Aiello et al. 2004, Aiello et al. 2005b].

Detailed magnetic data processing was performed to trace the high-resolution magnetic-anomaly map of the study area [Ruggieri 2006] (Figure 10). The qualitative interpretation of this map has allowed the identification of three main magnetic field anomalies (Figure 10). The first of these is located on the continental shelf, corresponding to the mouth of the Volturno River between the isobaths of 70 $\mathrm{m}$ and $100 \mathrm{~m}$ (Figure 10, area 1). It has a complex shape, as slightly elongated in an E-W direction, with a central minimum at $-700 \mathrm{nT}$.

Comparison with the AGIP aeromagnetic data shows that this anomaly that might have already been identified in previous studies [de Alteriis et al. 2002, 2006], is characterized by an inverted maximum-minimum axis. This supplies some information on the timing of the emplacement of the magnetic intrusion, which can presumably be attributed to the Early Pleistocene (prior to the age of the BruhnesMatuyama Reversal Boundary) [Sempere et al. 1987].

Another relevant magnetic field anomaly (Figure 10, area 2) that has a NE-SW trending with a magnetic maximum of about $200 \mathrm{nT}$ is located offshore of the Castelvolturno- 


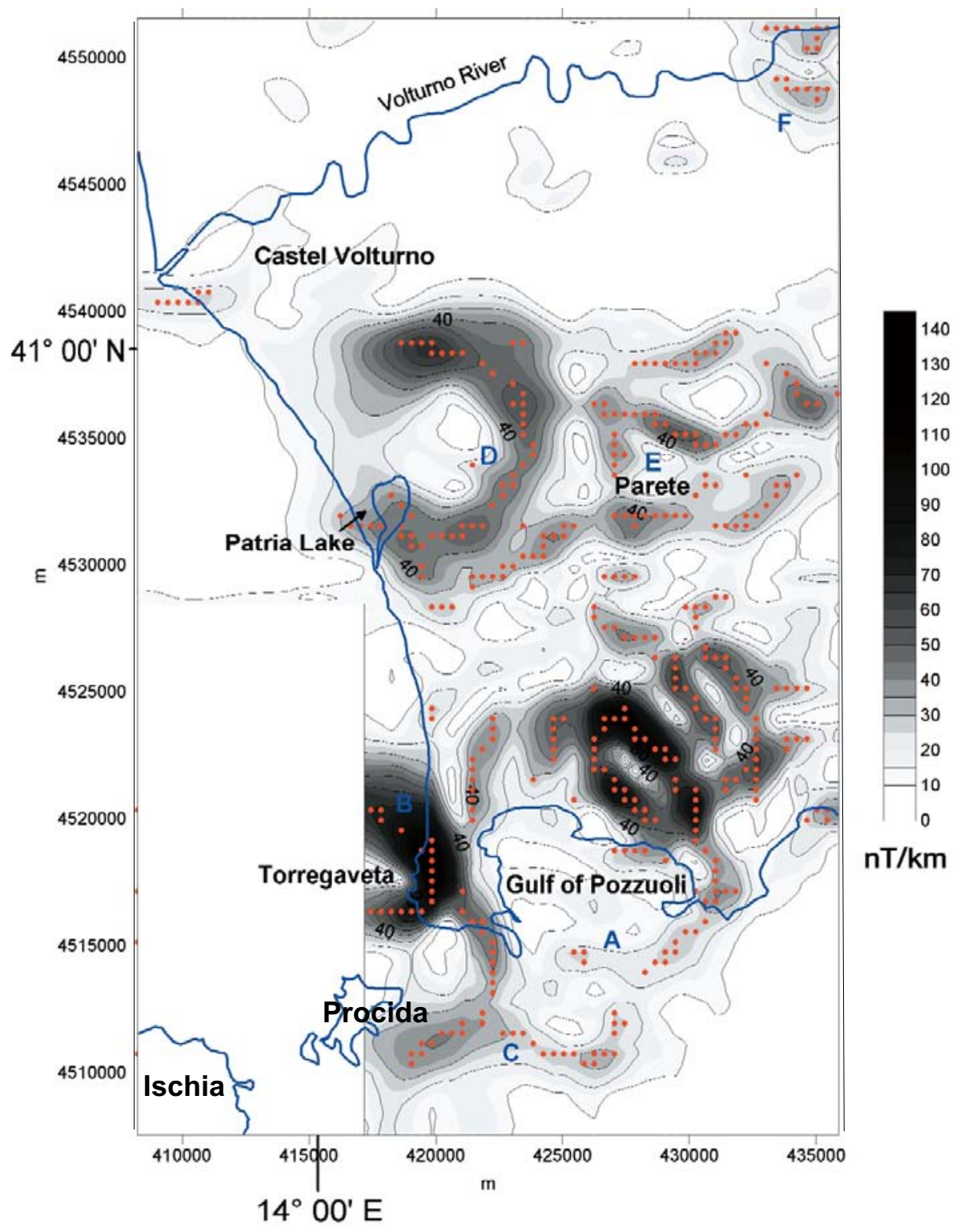

Figure 11. Map of the horizontal derivative plotted in the gray scale of the southern Volturno Plain (reported from Paoletti et al. [2004]). The letters A-F indicate the main magnetic anomalies recognized in the area (see main text).

Mondragone area. The regional geological framework and the correlation with seismic stratigraphy suggest that this field is related to a depocenter on the continental shelf, which corresponds to the Volturno Basin. The magnetic maximum might be controlled by the occurrence of a thick sedimentary cover (the filling of the Volturno Basin), which also encloses a significant amount of reworked pyroclastic products that have been drained by the Volturno River. The NE-SW trend of this magnetic anomaly area reflects the occurrence of counter-Apennine (NE-SW) normal faults, which have already been suggested by seismic interpretation [Bruno et al. 2000], and which control the overall tectonic setting of the continental shelf.

This interpretation is substantially in agreement with the results shown by Paoletti et al. [2004] (Figure 11). Although north of the $41^{\text {st }}$ parallel the area appears to be magnetically quiet [Lavecchia 1988, Spadini and Wezel 1994, Ferranti et al. 1996], in the NE corner of the map in Figure 11 there is an isolated and interesting anomaly. The same anomaly was plotted by Paoletti et al. [2004] as in the map of Figure 11 (red dots located offshore of Castelvolturno town). Similar to other very small anomalies detected south of the Volturno river (see Figure 11) [Paoletti et al. 2004], this demonstrates extensive volcanic activity in the Campania Plain. The presence of buried magnetized structures is reasonable also considering the lack of any surface geological evidence.

North of Procida Island there is a magnetic maximum of about $200 \mathrm{nT}$ (Figure 10, area 3). Although this requires more detailed analysis through further magnetic data gathering onsite, this maximum is related to the volcanic structures of the Phlegrean Fields and of Ischia and Procida Islands.

The Parete-Villa Literno area is characterized by weak magnetic anomalies with wavelengths of the order of tens of kilometers, and by thick volcanites that were detected in 
the «Parete 2» and «Villa Literno 2» geothermal wells [Baldi et al. 1976, Barbieri et al. 1976]. Moreover, the gravity high near Parete seen on the gravity maps of Cassano and La Torre [1987] can be interpreted as a volcanic structure [Baldi et al. 1976, Aprile and Ortolani 1979] or as a buried carbonate horst with magmatic intrusions along its rims [Carrara et al. 1973].

A new aeromagnetic map supplement of the northern sector of the Phlegrean Fields that contains new aeromagnetic data collected in 1999 and 2001 supports our data interpretation [Paoletti et al. 2004]. The magnetic map of the horizontal derivative (Figure 11) allows for better geological interpretation of the structural patterns and morpho-structural features of the Volturno Plain, starting from the Volturno River, and the Gulf of Pozzuoli and its offshore areas. The main magnetostructural features are the calderic rims of Neapolitan yellow tuff (Figure 11, A) and the Torregaveta anomaly (Figure 11, B). A small anomaly that corresponds to an isolated volcanic body is also indicated in Figure 11 (C).

All of the structures that appear in the central area appear to be aligned along an E-W trend, which is roughly coincident with the $41^{\text {st }}$ parallel fault system that is located at the mouth of the Volturno River [Lavecchia 1988, Spadini and Wezel 1994, Ferranti et al. 1996, Bruno et al. 2000]. The most important anomaly is the Patria Lake anomaly (Figure 11, D), which has a sub-circular shape and a diameter of about 10 $\mathrm{km}$. A complex pattern of magnetic anomalies (Figure 11, E) coincides with the Parete volcanic complex, and another isolated anomaly has been suggested that corresponds with the Volturno River (Figure 11, F).

\section{Discussion}

This seismo-stratigraphic study has focused on the Volturno Basin and it confirms the regional geological structure of the Campania-Latium continental margin, which is characterized by a series of structural highs and intervening basins that match the main structures on the mainland. The eventual implications for the tectono-stratigraphy of the other basins of the Campania and Latium margin (the Terracina and Gaeta basins) have also been analyzed.

The present study long-establishes the important role played by the Quaternary volcanic eruptions, and demonstrates the incidence of sedimentation of thick, acoustically transparent volcanic seismic sequences under the basin that are interconnected with the Villa Literno and Parete volcanic complexes. A qualitative correlation of the seismic and magnetic data has also been carried out, which was aimed at confirmation of the volcanic nature of the seismic units that have been predicted through geological interpretations (Figures 10 and 11).

The regional tectonic lineaments of the CampaniaLatium Tyrrhenian margin illustrated in Figure 1 are summarized here: the NW-SE trending Circeo Structural High, which represents the seaward extension of the Circeo

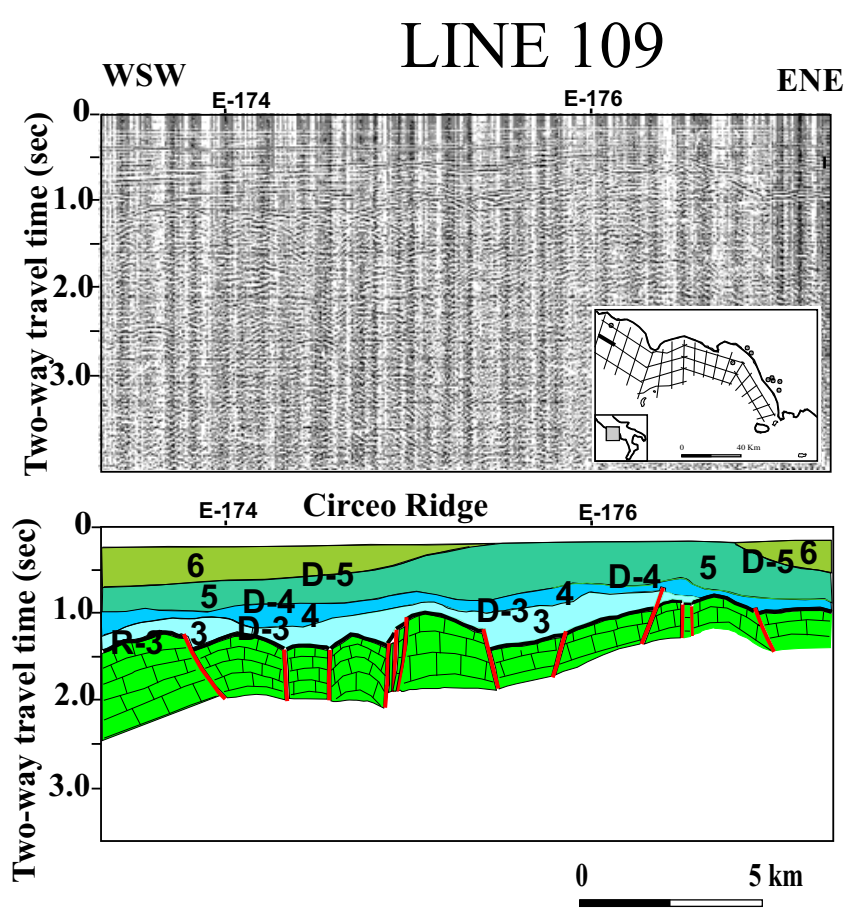

Figure 12. Seismic profile E109 (re-interpreted after Aiello et al. [2000]), showing the structural high of the Circeo ridge. Note that the structural high is intensively affected by normal faulting. Key: Regional unconformities: R-3, D-3, D-4, D-5. Seismic units: 3, 4, 5, 6.

Promontory (Figure 12); the Terracina Basin, which is a N-S trending half-graben that enlarges seawards and laterally joins the Gaeta Basin (Figure 5); The Terracina-Gaeta Structural High, which is a wide belt of structural highs outside Gaeta town that indicate the physiographic separation of the Terracina and Gaeta basins; the Massico Mount Structural High, a NE-SW trending structural high that is indicative of the seaward prolongation of the Mount Massico structure; and the Volturno Basin, which is characterized by a depocenter that corresponds with the mouth of the Volturno River (Figures 6 and 7).

The Plio-Pleistocene basin fill of the Terracina and Gaeta Basins constitutes siliciclastic deposits of marine, coastal and deltaic environments (conglomerates, sands and shales), which sometimes has intercalations of volcano-clastic levels, as documented by the offshore-well stratigraphy («Mara 1» exploration well) [Aiello et al. 2000] (Figure 1). These deposits overlie a succession that is about $1000 \mathrm{~m}$ thick, of alternating sands, shales and alluvial conglomerates, at the offshore well «Mara 1». The conglomerates are probably Late PlioceneEarly Pleistocene in age, and correspond to a seismic facies characterized by prograding clinoforms that are erosionally truncated at the top. These correlate with a similar succession that crops out onshore near Scauri and Minturno («Conglomerati di Scauri» Auct.) [Parotto and Praturlon 1975, Accordi and Carbone 1986].

The structural setting of the Terracina Basin is controlled by NNE-SSW trending normal faults that are mainly at its north-western margin. These faults spread to the west of the 


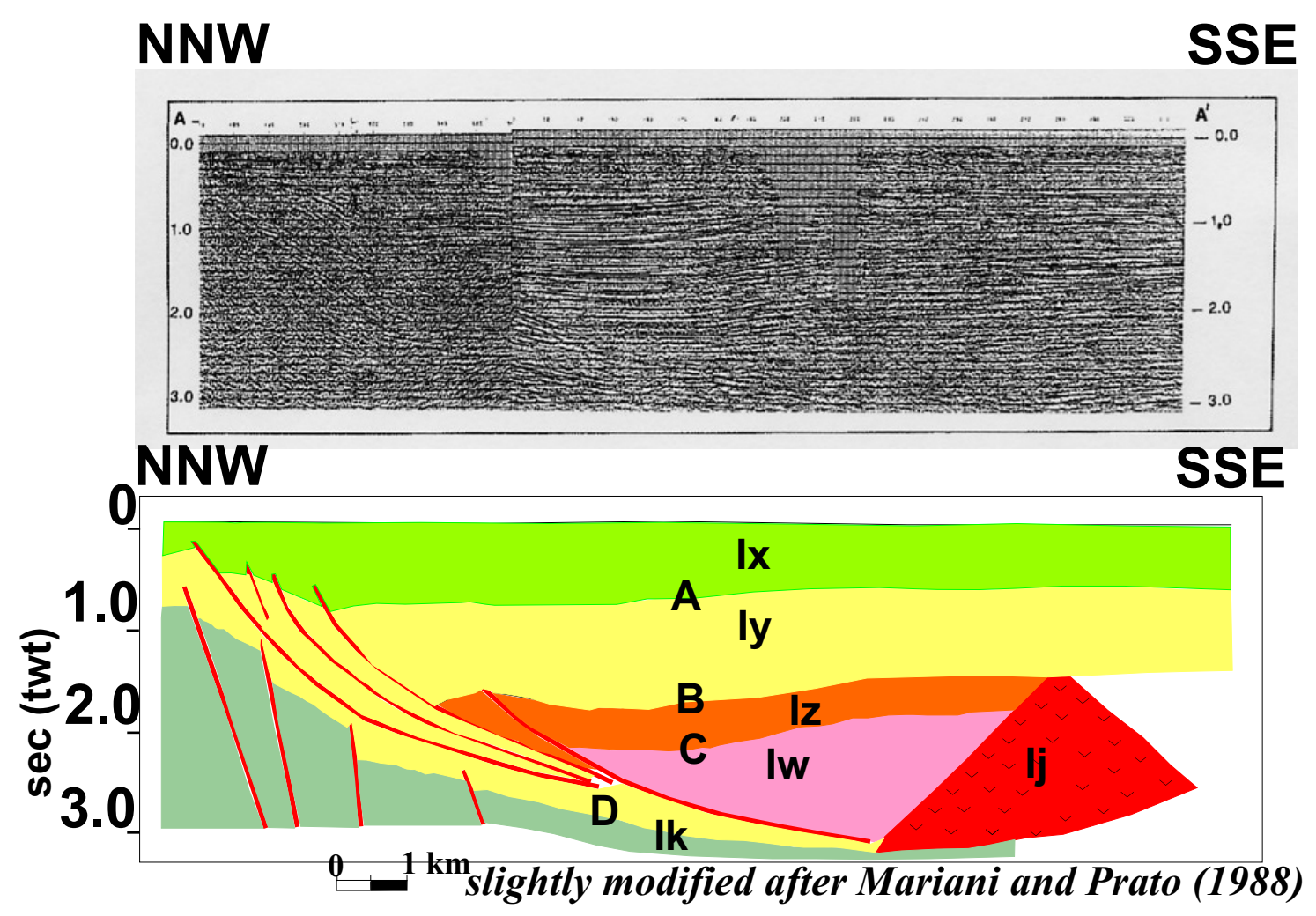

KEY

Ix Seismic unit composed of parallel reflectors having low continuity and varying amplitude Coastal clays (Pleistocene)

ly Seismic unit composed of continuous reflectors having high amplitude and sigmoidal patterns. Alternating deltaic sands and shales (Pleistocene)

Iz Seismic unit composed of discontinuous reflectors with high amplitude.

Alternating deltaic sands and shales (Pleistocene)

Iw Seismic unit composed of discontinuous chaotic reflectors with middle amplitude.

Alternating continental sandstones, conglomerates and shales with thin levels of volcanites (Pleistocene)

Ik Seismic unit composed of discontinuous chaotic reflectors with middle amplitude Shales with intercalations of sands (Early Pleistocene)

lj Volcanic rocks (Villa Literno volcanic complex) (Early Pleistocene)

Figure 13. Interpreted seismic section onshore in the Volturno Basin (modified after Mariani and Prato [1988]). Note the occurrence of four main onshore seismic sequences, that are correlated with the offshore seismic sequences identified based on the seismo-stratigraphic analysis of the Sister4_2 seismic profile (see also the Figures 6 and 7).

sedimentary basin, and only down throw the basin filling locally, and they border the southern flank of the Circeo Structural High. The same basin is bounded eastward by a structural high that is immediately offshore of the Gaeta area (the Gaeta Promontory), which marks the shift to the Gaeta Basin. The extensional deformation was probably active up to the early stages of the filling of the basin, as indicated by the wedging and growth of the basal seismic sequences.
The Gaeta Basin is E-W oriented and is characterized by two main depocenters. It is bounded to the north and to the south by E-W striking normal faults [Aiello et al. 2000, Bruno et al. 2000], and to the east by a NW-SE normal fault. At the northern margin of the basin there is a system of normal faults that are E-W oriented and that reach a throw of $<1 \mathrm{~s}$. The acoustic basement ranges in depth between 300 $\mathrm{ms}$ and $1 \mathrm{~s}$ in correspondence to the Gaeta Structural High 
(Figure 1), and it is composed of siliciclastic deposits (Flysch di Frosinone Auct.) [Parotto and Praturlon 1975] and JurassicCretaceous basinal carbonates; it is strongly affected by extensional tectonics. The eastern-most depocenter of the Gaeta Basin is enclosed towards the east by a NW-SE trending normal fault.

The Volturno Basin is bordered to the north-north-west by the NE-SW trending Massico Mount Structural High, to the east by NW-SE trending normal faults that down-throw the platform carbonates that crop out in the Caserta Mountains. It is also defined by volcanic rock that is genetically related to the Villa Literno volcanic complex, and to the west in the surrounding offshore by a volcanic structural high that is parallel to the shoreline and which represents a buried volcanic edifice at the mouth of the Volturno River [de Alteriis et al. 2006].

The Plio-Pleistocene basin fill (Castelvolturno 2 well) [Ippolito et al. 1973] is composed of marine deposits, with frequent pyroclastic levels and lagoon and deltaic conglomerates, which evolve upwards into marine sediments. The seismic interpretation of the onshore reflection seismics [Mariani and Prato 1988] allowed the identification of five seismic sequences, which include the volcanic seismic sequence related to the Villa Literno volcanic complex (Figure 13). The upper sequence (Figure 13, Ix) is Pleistocene in age and is branded by parallel and discontinuous reflectors with low amplitudes, and it is composed of clays of coastal environments. It is underlined by an erosional unconformity that grades into another Pleistocene seismic sequence (Figure 13, Iy), which is characterized by continuous seismic reflectors with progradational (sigmoidal) geometry, and is constituted by alternating sands and shales of deltaic environments. The underlying Pleistocene sequence (Figure 13, Iz) is distinguished by discontinuous and parallel seismic reflectors, and it is composed of sands that alternate with shales of deltaic environments. The lowest sequence (Figure 13, Iw) is identified by discontinuous seismic reflectors with poor continuity, and it is constituted by thin alternating sandstones, conglomerates and shales, with levels of Pleistocene volcanites. It was deposited in continental environments.

The geological interpretation of the Sister4_2 seismic profile has highlighted the relationships between the MesoCenozoic acoustic basement and the Quaternary basin filling, which include significant volcanic terms.

The Meso-Cenozoic acoustic basement is composed of two main seismic facies, which are interpreted as the MesoCenozoic carbonates (Figure 7, MC) and the overlying siliciclastic (flysch) deposits (Figure 7, FLS). The MesoCenozoic carbonates show a seismic facies with scattered and discontinuous seismic reflectors, which is of high amplitude. Their top is marked by strong erosional unconformity, at depths between $1800 \mathrm{~m}$ and $1950 \mathrm{~m}$. The overlying Cenozoic deposits show a chaotic seismic facies and are intensively deformed by normal faulting. Their top is marked by a strong erosional unconformity, at depths between $1125 \mathrm{~m}$ and $1350 \mathrm{~m}$. This sequence correlates with the Miocene deposits of the «Flysch of Frosinone» Auct. [Parotto and Praturlon 1975].

A thick, acoustically transparent, seismic sequence overlying the unconformity located at the top of the Miocene flysch deposits is interpreted as volcanites that are genetically related to the volcanic deposits of the Villa Literno volcanic complex. The average thickness of this sequence has been estimated at about $400 \mathrm{~m}$.

The considerable amount of lava drilled by the «Parete 2» and «Villa Literno 2» litho-stratigraphic wells (Figure 4), along with the buried volcanic complexes seen on the Sister4_2 seismic section (Figure 7), suggest the occurrence of volcanic complexes that are now fossilised and buried, with their probable effusive centers completely covered by recent alluvial and pyroclastic deposits. These volcanic complexes also extend seawards, and they were probably located between the low course of the Volturno River and the northern margin of the Phlegrean Fields.

The stratigraphy of the Campania Plain can be summarized as follows [Ortolani and Aprile 1978]: alluvial deposits and volcanites thick 3000-3500 $\mathrm{m}$ (in the central sector), Tertiary terrigenous deposits, thick several hundred of meters, ranging in age from the late Miocene to the Pliocene, carbonatic units of the Campania-Lucania Carbonate Platform at depths from $4000 \mathrm{~m}$ to $4500 \mathrm{~m}$ down to $6500 \mathrm{~m}$ to $7000 \mathrm{~m}$, and finally, carbonatic units of the Abruzzi-Campania Carbonate Platform.

\section{Concluding remarks}

Four main seismic sequences that correspond to the seismic units recognized onshore by Mariani and Prato [1988] have been distinguished in the Volturno Basin, based on seismo-stratigraphic analysis of the Sister4_2 seismic profile. The lithology of the seismic units of the filling of the Quaternary basin has been inferred both from the lithostratigraphic data of the "Castelvolturno 2» deep borehole (Figure 3) and from the study of Mariani and Prato [1988].

The first seismic sequence (Figure 7, profile 1) is characterized by discontinuous to continuous seismic reflectors that are from parallel to sub-parallel. They are probably composed of sands, conglomerates and shales, with levels of pyroclastites, and their age is probably Early Pleistocene [Mariani and Prato 1988]. The sequence on-laps onto the flank of the VC volcanic seismic unit (Figure 7), which represents volcanites genetically related to the Villa Literno volcanic complex. It is characterized by wedging geometries, which suggests its emplacement during the activity of synsedimentary tectonic extension. The intrusion of the VC volcanic unit is probably older than the deposition of seismic unit 1 , as is suggested by the on-lap of the above- 
mentioned unit on the flanks of the volcanic rock.

The second seismic sequence (Figure 7, profile 2) has been subdivided into two main seismic facies that have been identified on the continental shelf (Figure 7, seismic sequence $2 \mathrm{a}$ ) and the basin (Figure 7 , seismic sequence $2 \mathrm{~b}$ ). Sequence $2 \mathrm{a}$ is characterized by prograding clinoforms and has been interpreted as a relic prograding wedge that downlaps onto volcanites. Seismic unit $2 \mathrm{~b}$ is characterized by parallel to sub-parallel seismic reflectors, and it is probably constituted by alternating sands and shales of deltaic environments (Pleistocene).

The third seismic sequence (Figure 7 , profile 3 ) is identified by parallel to sub-parallel seismic reflectors with high amplitude, and it is formed by alternating sands and shales of deltaic environments.

Finally, the fourth seismic sequence (Figure 7, profile 4) shows discontinuous to continuous and parallel to subparallel seismic reflectors. It is probably composed of clays of coastal environments (Pleistocene).

The seismic interpretation of the Sister4_2 multichannel profile has contributed to our knowledge of the stratigraphic and structural relationships between the MesoCenozoic acoustic basement and the filling of the Quaternary basin in the Volturno Basin, on the northern Campania continental margin. The overall seismostratigraphic data is in agreement with Mariani and Prato [1988], and confirms that the Volturno Basin is a half-graben structure that is characterized by down-thrown blocks along normal faults that affect mainly the top of the Miocene acoustic basement.

As in the other sedimentary basins offshore of the Campania Region [see also Aiello et al. 2005b], the volcanic deposits appear to be well developed as offshore buried volcanic complexes. This is the case for the volcanic bodies identified on the Sister4_2 seismic profile that are genetically related to the Villa Literno volcanic complex. The filling of the Quaternary basin is composed of thick sediments of delta, lagoon and marine environments. It shows stratigraphic relationships of facies hetheropy with pyroclastic and lavic complexes. As a general rule, the depositional geometries of the filling of the sedimentary basin often appear to be conditioned by the buried volcanic complexes, especially at the contact between the acoustically transparent volcanites and the marine sediments. This had already been suggested in the case histories of the Bay of Naples [Aiello et al. 2005b] and of the mouth of the Volturno River [de Alteriis et al. 2006], where buried volcanic complexes have been identified and studied in detail through seismic interpretation.

Comparison of the data from the Volturno basin with the commercial seismic data of "Zone E» (AGIP) has been carried out. This refers in particular to the Terracina and Gaeta basins, which represent further examples of half- graben basins on the Campania-Latium Tyrrhenian margin [Aiello et al. 2000] (Figures 5, 8, 9 and 12).

The tectonic extension is revealed by NE-SW (counter Apenninic) and E-W trends of normal faults that control the formation of N-S to E-W oriented half-graben structures on the Campania-Latium Tyrrhenian margin (Terracina, Gaeta and Volturno basins), according to Oldow et al. [1993] and Ferranti et al. [1996]. The older extensional phase, which is Pliocene in age, acted through NW-SE (Apenninic) normal faults, which controls the structural setting of the investigated area. In correspondence with the Tyrrhenian coastal belt, NW-SE trending sedimentary basins and intervening ridges distinguish the physiography of the Campania continental margin. Lastly, the Pleistocene extensional phase acts through high-angle normal faults with counter-Apennine trends, and it is responsible for the most recent deformations and for the general down-throwing of the western Apenninic margin towards the central Tyrrhenian Sea.

A semi-quantitative kinematic model explaining the relationships between the extension in the Tyrrhenian Sea, the basin formation, the migration of the Apenninic arcs, and the geotectonic setting of the volcanism has been recently elaborated by Turco et al. [2006]. The extension directions in various sectors of the Apennine chain have been compared with the results of the morpho-structural analysis. Two distinct kinematic elements, the Northern Apennine Arc and the Southern Apennine Arc, have moved independently and have undergone two stages of rotation. During the first stage, ranging in age between 3.5 My and $0.78 \mathrm{My}$, the two arcs migrated independently; in the second stage, ranging in age from $0.78 \mathrm{My}$ to the present, the Northern Apenninic Arc stopped its migration, while the Southern Apenninic Arc continued moving toward the SE. The N-S extension in the Campania Plain was a consequence of the motion of the Northern Apenninic Arc during the first stage of rotation, while the NW-SE extension is related to the south-eastwards migration of the Southern Apennines with respect to the Northern Apennines.

The results obtained are not in disagreement with those shown by some previous geological sections carried out on the Campania continental margin, both at a crustal [Milia et al. 2003, Sartori et al. 2004] and at intermediate [Aiello et al. 2009] scales. The structure of the continental margin is controlled by asymmetric-linked fault systems, which are characterized by a main detachment level, listric normal faults, and rollover anticlines. Deep seismic reflection data collected during the Ocean Drilling Program cruises [Sartori et al. 2004] have revealed the conjugate structure of the Campania and Sardinia passive continental margins. Plio-Quaternary depocenters (more than $1.4 \mathrm{~s} \mathrm{twt}$ ) occur close to the base of the continental margin, and are in small half-graben basins that are bounded by faults that trend from N-S to NW-SE. 
The continental margins of the southern Tyrrhenian basin are highly asymmetric because the rifting processes were overcome by a low-angle, easterly dipping, and crustal detachment fault [Trincardi and Zitellini 1987, Kastens et al. 1988]. The geological transects have confirmed the asymmetric nature of the conjugate margin pairs of Sardinia-Campania, which extend down to the Moho depth [Sartori et al. 2004].

Although the scale of the multi-channel profile analyzed here did not allow for the identification of deep detachment levels, which are usually identified on seismic reflection or refraction profiles recorded at a crustal scale, we can hypothesize that the portion of the continental margin investigated shows only the upper part of listric normal faults (Bally et al. [1985]: 'high-angle normal faults'), while the 'lowangle normal faults' and the 'sole faults' might be located at greater depths. Therefore, the nature of the 'growth faults' [Bally et al. 1985] of the interpreted structural lineaments is suggested by the wedging and growth of the basal sequences of the Quaternary filling.

Acknowledgements. This study was funded by CNR grants to E. Marsella (IAMC-CNR, Naples, Italy). We thank all of the participants to the SISTER oceanographic cruise and the crew of the R/V Urania (National Research Council of Italy) for their assistance during the seismic-data acquisition. We wish to thank three anonymous referees, whose comments greatly improved the manuscript. We also thank Prof. Edoardo Del Pezzo and Mario La Rocca (INGV, Osservatorio Vesuviano) for their support.

\section{References}

Accordi, G. and F. Carbone (1986). Lithofacies map of LatiumAbruzzi and neighbouring areas, Scale 1:250.000, Quaderni de "La Ricerca Scientifica", CNR, Roma, 114, 5.

Aiello, G., I. Aquino and M. Sacchi (1996). Assetto tettono-stratigrafico dei bacini plio-pleistocenici di Terracina e di Gaeta (Tirreno centro-orientale), In: Atti Riunione GIS (Catania, ottobre 1996), 39-42.

Aiello, G., E. Marsella and M. Sacchi (2000). Quaternary structural evolution of Terracina and Gaeta basins (eastern Tyrrhenian margin, Italy), Rend. Lincei-Sci. Fis., 9, 11-41.

Aiello, G., A. Angelino, E. Marsella, S. Ruggieri and A. Siniscalchi (2004). Carta magnetica di alta risoluzione del Golfo di Napoli (Tirreno meridionale), B. Soc. Geol. Ital., 123, 333-342.

Aiello, G., A. Angelino, E. Marsella, S. Ruggieri and A. Siniscalchi (2005a). Nuovi dati magnetici di alta risoluzione acquisiti tra il Golfo di Gaeta e l'Isola d'Ischia, Ext. Abs. GNGTS, Roma, $24^{\circ}$ Conv. Naz., 502-503.

Aiello, G., A. Angelino, B. D'Argenio, E. Marsella, N. Pelosi, S. Ruggieri and A. Siniscalchi (2005b). Buried volcanic structures in the Gulf of Naples (Southern Tyrrhenian sea, Italy) resulting from high resolution magnetic survey and seismic profiling, Annals of Geophysics, 48 (6), 883-897.

Aiello, G., E. Marsella, V. Di Fiore, C. D'Isanto (2009). Stratigraphic and structural styles of half-graben offshore basins in Southern Italy: multichannel seismic and Multi- beam morpho-bathymetric evidences on the Salerno Valley (Southern Campania continental margin, Italy), Quaderni di Geofisica, 77, 1-33; ISSN 1590-2595.

Aprile, F. and F. Ortolani (1979). Sulla struttura profonda della Piana Campana, Boll. Soc. Natural. in Napoli, 88, 1-19.

Ascione, A. and P. Romano (1999). Vertical movements on the eastern margin of the Tyrrhenian extensional basin. New data from Mt. Bulgheria (Southern Apennines, Italy), Tectonophysics, 315, 337-356.

Baldi, P., G.M. Cameli, B. D'Argenio, A. Oliveri Del Castillo, T. Pescatore, L. Puxeddu, A. Rossi and B. Toro (1976). Geothermal research in Western Campania (Southern Italy): a revised interpretation of the Qualiano-Parete structure, In: Proc. of the Int. Conf. «Thermal Waters, Geothermal Energy and Volcanism of the Mediterranean Area», Athens.

Bally, A.W., R. Catalano and J. Oldow (1985). Elementi di Tettonica Regionale, Bologna, Italy, Pitagora Editrice, $276 \mathrm{pp}$.

Barberi, F., E. Cassano, P. La Torre, and A. Sbrana (1991). Structural evolution of Campi Flegrei caldera in light of volcanological and geophysical data, J. Volcanol. Geoth. Res., 48 (1-2), 33-49.

Barbieri, M., P. Di Girolamo, E. Locardi, G. Lombardi, D. Stanzione and M. Nicoletti (1976). Geothermal research in Western Campania (Italy): stratigraphy of the Parete exploratory well and new data on the volcanic sequence, In: Proceedings of the Int. Conf. «Thermal Waters, Geothermal Energy and Volcanism of the Mediterranean Area», Athens.

Bartole, R., C. Savelli, M. Tramontana and F.C. Wezel (1983). Structural and sedimentary features in the Tyrrhenian margin off Campania, southern Italy, Mar. Geol., 55, 163-180.

Bartole, R. (1984). Tectonic structure of the Latian-Campanian shelf, B. Oceanol. Teor. Appl., 2 (3), 197-230.

Bertotti, G., E. Marsella, F. Pepe, R. Tonielli and the Sister99 Shipboard Scientific Party (1999). Sister99: a seismic campaign to investigate the kinematics of South Tyrrhenian extensional regions, Giorn. Geol., 61 (3), 25-36.

Brancaccio, L., A. Cinque, P. Romano, C. Rosskopf, F. Russo, N. Santangelo and A. Santo (1991). Geomorphology and neotectonic evolution of a sector of the Tyrrhenian flank of the Southern Apennines, Z. Geomorphol., 82, 47-58.

Brocchini, D., C. Principe, D. Castradori, M.A. Laurenzi and L. Gorla (2001). Quaternary evolution of the southern sector of the Campanian Plain and early Somma-Vesuvius activity: insights from the Trecase 1 well, Miner. Petrol., 73, 67-91.

Bruno, P.P.G., V. Di Fiore and G. Ventura (2000). Seismic study of the $41^{\text {st }}$ Parallel Fault System offshore the CampanianLatial continental margin, Tectonophysics, 324, 37-55.

Cameli, G.M., M. Rendina, M. Puxeddu, A. Rossi, P. Squarci, and L. Taffi (1975). Geothermal research in Western Campania (Southern Italy). A revised interpretation of 
the Qualiano-Parete structure, Symp. on «Geotechnics and Volcanism of Mediterranean area», Athens, Greece.

Carrara, E., F. Iacobucci, E. Pinna and A. Rapolla (1973). Gravity and magnetic survey of the Campanian volcanic area, Southern Italy, B. Geofis. Teor. Appl., XV (57), 39-51.

Carrara, E., F. Iacobucci, E. Pinna and A. Rapolla (1974). Interpretation of gravity and magnetic anomalies near Naples, using computer techniques, B. Volcanol., 38 (1), 458-467.

Cassano, E. and P. La Torre (1987). Geophysics, In: R. Santcroce (ed.), Somma-Vesuvius, Quaderni de "La Ricerca Scientifica", CNR, Roma, 114 (8), 175-192.

D'Argenio, B., T. Pescatore and P. Scandone (1973). Schema geologico dell'Appennino meridionale (Campania e Lucania), In: «Moderne Vedute sulla Geologia dell'Appennino", Convegno (Roma, 16-18 Febbraio 1972), Accad. Naz. dei Lincei, Problemi Attuali di Scienza e Cultura, Quaderni, 183, 49-72.

de Alteriis, G., M. Fedi, S. Passaro and A. Siniscalchi (2002). Geologically constrained seismic/magnetic modeling: an example from the Campania offshore at $41^{\circ} \mathrm{N}$ (Italy, Tyrrhenian sea), B. Geofis. Teor. Appl., 42 (1-2), 281-284.

de Alteriis, G., M. Fedi, S. Passaro and A. Siniscalchi (2006). Magneto-seismic interpretation of subsurface volcanism in the Gaeta Gulf (Italy, Tyrrhenian sea), Annals of Geophysics, 49 (4-5), 929-943.

De Vivo, B., G. Rolandi, P.B. Gans, A. Calvert, W.A. Bohrson, F.J. Spera and H.E. Belkin (2001). New constraints on the pyroclastic eruptive history of the Campanian volcanic Plain (Italy), Miner. Petrol., 73, 47-65.

Di Girolamo, P., M.R. Ghiara, L. Lirer, R. Munno, G. Rolandi and D. Stanzione (1984). Vulcanologia e petrologia dei Campi Flegrei, B. Soc. Geol. Ital., 103, 349-413.

Fedi, M. and A. Rapolla (1987). The Campanian Volcanic area: analysis of the magnetic and gravimetric anomalies, B. Soc. Geol. Ital., 106, 793-805.

Ferranti, L., J.S. Oldow and M. Sacchi (1996). Pre-Quaternary orogen parallel extension in the Southern Apennines belt, Italy, Tectonophysics, 260, 247-325.

Florio, G., M. Fedi, F. Cella, A. Rapolla (1999). The Campanian Plain and Phlegrean Fields: structural setting from potential field data, J. Volcanol. Geoth. Res., 91, 361-379.

Gillot, P.Y., S. Chiesa, G. Pasquarè and L. Vezzoli (1982). 33.000 $\mathrm{yr} \mathrm{K} / \mathrm{Ar}$ dating of the volcano-tectonic horst of the isle of Ischia, gulf of Naples, Nature, 229, 242-245.

Ippolito, F., F. Ortolani and M. Russo (1973). Struttura marginale tirrenica dell'Appennino campano: reinterpretazioni di dati di antiche ricerche di idrocarburi, Mem. Soc. Geol. Ital., 12, 123-132.

Kastens, K., J. Mascle and ODP Leg 107 Scientific Party (1988). ODP Leg 107 in the Tyrrhenian sea: Insights into passive margin and back-arc basin evolution, Geol. Soc. Am. Bull., 100, 1140-1156.

Korevaar, A., A. Pagano, V. Vandeweijer, G. Bertotti, E. Mar- sella and F. Pepe (2000). Regional seismic lines across and along the Campania passive continental margin, EUG General Assembly (Nice, April 2000).

Latmiral, G., A.G. Segre, M. Bernabini and L. Mirabile (1971). Prospezioni sismiche per riflessione nei Golfi di Napoli e Pozzuoli ed alcuni risultati geologici, B. Soc. Geol. Ital., 90, 163-172.

Lavecchia, G. (1988). The Tyrrhenian-Apennines system: structural setting and seismo-tectogenesis, Tectonophysics, 147, 263-296.

Maino, A., A.G. Segre and G. Tribalto (1963a). Risultati e interpretazioni del rilevamento gravimetrico della zona flegreo-vesuviana e dell'Isola d'Ischia, In: Atti XIII Convegno dell'Ass. Geof. Ital., Roma.

Maino, A., A.G. Segre and G. Tribalto (1963b). Rilevamento gravimetrico dei Campi Flegrei e dell'Isola d'Ischia, Annali dell'Osservatorio Vesuviano, series 6, vol. V.

Mariani, M. and R. Prato (1988). I bacini neogenici costieri del margine tirrenico: approccio sismico-stratigrafico, Mem. Soc. Geol. Ital., 41, 519-531.

Marsella, E., G. Aiello, A. Angelino, P.P.G. Bruno, V. Di Fiore, F. Giordano, N. Pelosi, A. Siniscalchi, C. D'Isanto and S. Ruggieri (2002). Shallow geological structures and magnetic anomalies in the Gulf of Naples. An integrated analysis of seismic and magnetometric profiles, B. Geofis. Teor. Appl., 42 (1-2), 292-297.

Masci, F., P. Palangio and M. Di Persio (2008). The INGV tectonomagnetic network, Adv. Geosci., 14, 65-68.

Milia, A., M.M. Torrente, M. Russo and A. Zuppetta (2003). Tectonics and crustal structure of the Campania continental margin: relationships with volcanism, Miner. Petrol., 79, 33-47.

Mitchum, R.M., P.R. Vail and S. Thompson (1977). Seismic stratigraphy and global changes of sea level. Part 2: The depositional sequence as a basic unit for stratigraphic analysis, In: Seismic Stratigraphy - Application to Hydrocarbon Exploration, ed. by C.E. Payton, AAPG Mem. 26, 53-62.

Oldow, J.S., B. D'Argenio, L. Ferranti, E. Marsella, G. Pappone and M. Sacchi (1993). Large scale longitudinal extension in the Southern Apennines contractional belt, Geology, 21, 1123-1126.

Oliveri Del Castillo, A. (1966). Considerazioni gravimetriche sul bacino eruttivo e sedimentario campano (anomalie residue di ordine n-I), Annali dell'Osservatorio Vesuviano, series 6, vol. VIII.

Ortolani, F. and F. Aprile (1978). Nuovi dati sulla struttura profonda della Piana Campana a sud-est del fiume Volturno, B. Soc. Geol. Ital., 97, 591-608.

Ortolani, F. and M. Torre (1981). Guida all'escursione nell'area interessata dal terremoto del 23-11-1980, Rend. Soc. Geol. Ital., 4 (2), 173-214.

Paoletti, V., M. Fedi, G. Florio, R. Supper and A. Rapolla (2004). 
The new integrated aeromagnetic map of the Phlegrean Fields volcano and surrounding areas, Annals of Geophysics, 47 (5), 1569-1580.

Parotto, M. and A. Praturlon (1975). Geological summary of Central Apennines, Quaderni de "La Ricerca Scientifica", CNR, Roma, 90, 257-311.

Rolandi, G., F. Bellucci, M.T. Heizler, H.E. Belkin, and B. De Vivo (2003). Tectonic controls on the genesis of ignimbrites from the Campanian Volcanic Zone, southern Italy, Miner. Petrol., 79, 3-31.

Romano, P., A. Santo and M. Voltaggio (1994). L'evoluzione geomorfologica della pianura del fiume Volturno (Campania) durante il tardo Quaternario (Pleistocene MedioSuperiore-Olocene), Il Quaternario, 7 (1), 41-58.

Rosi, M. and A. Sbrana (1987). Phlegrean Fields, Quaderni de "La Ricerca Scientifica", CNR, Roma, 114, 9.

Ruggieri, S. (2006). Applicazione di metodologie di geofisica marina allo studio dei margini continentali in aree vulcaniche attive: carta magnetica di alta risoluzione del margine continentale campano-laziale tra i Golfi di Gaeta e Napoli (Tirreno centro-meridionale) e correlazione con $\mathrm{i}$ principali lineamenti morfo-strutturali, Tesi di Dottorato di Ricerca, Università degli Studi di Napoli «Federico II»; available online at: http: / / www.fedoa.unina.it/634/ .

Sartori, R., L. Torelli, N. Zitellini, G. Carrara, M. Magaldi and P. Mussoni (2004) Crustal features along a W-E transect from Sardinia to Campania margins (Central Mediterranean), Tectonophysics, 383, 171-192.

Scandone, R., F. Bellucci, L. Lirer and G. Rolandi (1991). The structure of the Campanian Plain and the activity of the Neapolitain volcanoes (Italy), J. Volcanol. Geoth. Res., 48, 1-31.

Sempere, J.C., K. Macdonald and S.P. Miller (1987). Detailed Study of the Bruhnes/Matuyama Reversal Boundary on the East Pacific Rise at $19^{\circ} 30^{\prime} \mathrm{S}$ : Implications for Crustal Emplacement Processes at an Ultra Fast Spreading Center, Mar. Geophys. Res., 9, 1-23.

Spadini, G.. and F.C. Wezel (1994). Structural evolution of the $41^{\text {st }}$ parallel zone; Tyrrhenian sea, Terra Nova, 6, 552-562.

Telford, W.M., L.P. Geldart and R.E. Sheriff (1990). Applied Geophysics. Cambridge University Press., $2^{\text {nd }}$ Edition, $770 \mathrm{pp}$.

Trincardi, F. and N. Zitellini (1987). The rifting of the Tyrrhenian basin. Geomar. Lett., 7, 1-6.

Turco, E., A. Schettino, P.P. Pierantoni and G. Santarelli (2006). The Pleistocene extension of the Campania Plain in the framework of the Southern Tyrrhenian tectonic evolution: morphotectonic analysis, kinematic model and implications for volcanism, In: Volcanism in the Campania Plain - Vesuvius, Campi Flegrei and Ignimbrites, edited by B. De Vivo, Dev. Volcano., 9, 27-51.

Vail, P.R. , R.M. Mitchum and S.T. Thompson (1977). Seismic Stratigraphy and global changes of sea level, In: Seismic
Stratigraphy - Application to Hydrocarbon Exploration, edited by C.E. Payton, 49-212.

Zitellini, N., M. Marani and A. Borsetti (1984). Post-orogenic tectonic evolution of Palmarola and Ventotene basins (Pontine Archipelago), Mem. Soc. Geol. Ital., 27, 121-131.

\footnotetext{
${ }^{\star}$ Corresponding author: Gemma Aiello, Istituto per l'Ambiente Marino Costiero (IAMC), Consiglio Nazionale delle Ricerche, Sede di Napoli, Calata Porta di Massa, Naples, Italy; email: gemma.aiello@iamc.cnr.it.

(C) 2011 by the Istituto Nazionale di Geofisica e Vulcanologia. All rights reserved.
} 